\title{
BİST İmalat Sektöründeki Küçük Boyuttaki ve Orta Ölçekteki İşletmelerin Sermaye Yapısına Etki Eden Faktörlerin Kanonik Korelasyon Analizi İle Karşılaştırmalı Olarak İncelenmesi $^{1}$
}

\author{
(Comparative Analysis of Factors Affecting the Capital Structure of Small and Medium \\ Enterprises in BIST Manufacturing Sector Using Canonical Correlation Analysis)
}

\author{
Nilüfer YÜCEDAĞ ERDİNÇ iDa Güven SAYILGAN iD \\ an.yucedagerdinc@gmail.com \\ b Ankara Üniversitesi, Siyasal Bilgiler Fakültesi, Ankara, Türkiye. sayilgan@ankara.edu.tr
}

\begin{tabular}{|c|c|}
\hline MAKALE BİLGİSİ & ÖZET \\
\hline $\begin{array}{l}\text { Anahtar Kelimeler: } \\
\text { Sermaye Yapısı } \\
\text { İmalat İşletmeleri } \\
\text { Kanonik Korelasyon Analizi }\end{array}$ & $\begin{array}{l}\text { Amaç - Bu çalışmanın amacı, Borsa İstanbul'da kayıtlı olan küçük ve orta ölçekli imalat sektörü } \\
\text { işletmelerinin sermaye yapısına etki eden işletmeye özgü ve makroekonomik değişkenlerin; } \\
\text { işletmelerin sermaye yapısı kararları ile ilişkisinin karşılaştırmalı olarak incelenmesidir. Böylece, } \\
\text { küçük ve orta ölçekli imalat sektörü işletmelerinin sermaye yapısı kararlarına etki eden faktörlerin } \\
\text { birbirlerinden farklı olup olmadıkları veya ne ölçüde farklı oldukları gösterilebilecektir. }\end{array}$ \\
\hline $\begin{array}{l}\text { Gönderilme Tarihi } 12 \text { Ocak } \\
2020 \\
\text { Revizyon Tarihi } 15 \text { Mart } 2020 \\
\text { Kabul Tarihi } 20 \text { Mart } 2020\end{array}$ & $\begin{array}{l}\text { Yöntem - 2009-2017 yılları arasında Borsa İstanbul'da faaliyette bulunan } 134 \text { imalat sektörü } \\
\text { işletmesi aktif büyüklüklerine göre gruplandırılmıştır. Gruplandırma sonucunda } 110 \text { işletme aktif } \\
\text { büyüklügüne göre küçük ve orta büyüklükteki (KOBİ) işletme olarak sınıflandırılmıştır. Analizde } \\
\text { işletmelere ait çeyrek dönem verileri kullanılmıstır. Kısa vadeli kaldıraç, uzun vadeli kaldıraç ve } \\
\text { toplam kaldıraç oranları bağımlı değişken olarak kullanılırken, işletmeye özgü bağımsı } \\
\text { değişkenler; karlılık, işletme büyüklügü, likidite, büyüme fırsatı ve varlık yapısı; makroekonomik } \\
\text { bağımsız değişkenler ise GSYİH büyüme oranı, faiz oranı ve döviz kuru oranı olarak ele alınmıştır. } \\
\text { Yöntem olarak kanonik korelasyon analizi tercih edilmiş, böylece işletmeye özgü değişkenler ile } \\
\text { makroekonomik değişkenlerin eş zamanlı olarak analizi mümkün olmuştur. }\end{array}$ \\
\hline $\begin{array}{l}\text { Makale Kategorisi: } \\
\text { Araştırma Makalesi }\end{array}$ & $\begin{array}{l}\text { Bulgular - Analiz sonuçlarına göre; toplam kaldıraç oranı en fazla katkı sağlayan kaldıraç değişkeni } \\
\text { olurken, işletmeye özgü değişkenler arasında en fazla katkı sağlayan değişken likidite değişkeni } \\
\text { olmuş ve kaldıraç oranlarıyla arasında negatif ilişki tespit edilmiştir. Makroekonomik değişkenler } \\
\text { içerisinde döviz kuru oranı en fazla katkı sağlayan değişken olup kaldıraç oranlarıyla arasında } \\
\text { negatif ilişki tespit edilmiştir. }\end{array}$ \\
\hline & $\begin{array}{l}\text { Tartışma - İşletmelerin sermaye yapılarını nasıl seçeceği ve makroekonomik faktörlerin karar verme } \\
\text { sürecini nasıl etkileyeceği finans literatürünün üzerinde hala çalışmaya devam ettiği konulardan } \\
\text { birisidir. İşletmelerin finansal karar verme sürecinde etkili olan sermaye yapısı belirleyicilerinin } \\
\text { incelendiği bu çalışmada, küçük ölçekli ve orta ölçekli olarak sınıflandırılan imalat işletmelerinin } \\
\text { hem finansman hiyerarşisi teorisine hem de dengeleme teorisine uygun hareket ettikleri } \\
\text { belirlenmiştir. İşletmelerin borçlanma davranışlarının genel olarak birbirine benzer olduğu ve } \\
\text { literatür incelendiğinde sermaye yapısı kararlarına etki eden faktörlere ilişkin araştırmalarda } \\
\text { kanonik korelasyon analizi kullanılan çalışmalara rastlanılmadığı aynı zamanda diğer analiz } \\
\text { yöntemleri kullanılarak yapılan çalışmalar ile benzer sonuçlar elde edildiği tespit edilmiştir. }\end{array}$ \\
\hline
\end{tabular}

\begin{tabular}{ll}
\hline ARTICLE INFO & ABSTRACT \\
\hline Keywords: & $\begin{array}{l}\text { Purpose - The aim of this study is to investigate the firm specific and the macroeconomic factors } \\
\text { affecting the capital structure decisions of small and medium sized manufacturing firmswhich are } \\
\text { traded at Borsa İstanbul. It is a comparative analysis of the relationship between firms and capital } \\
\text { Capital Structure }\end{array}$ \\
$\begin{array}{l}\text { Manufacturing Firms } \\
\text { structure decisions. Thus, it can be shown whether the factors affecting the capital structure } \\
\text { decisions of small and medium sized manufacturing sector enterprises are different from each other } \\
\text { onalysis }\end{array}$ & $\begin{array}{l}\text { Design/methodology/approach }- \text { The period of } 2009-2017, \text { a sample of } 134 \text { manufacturing firms, } \\
\text { operating in Borsa Istanbul are grouped according to their asset sizes. As a result of the grouping, } \\
\text { 110 firms are classified as small and medium sized (SME) enterprises according to their asset size. }\end{array}$ \\
\hline
\end{tabular}

${ }^{1}$ Bu çalışmaya, Prof. Dr. Güven Sayılgan danışmanlığında Nilüfer Yücedağ Erdinç'in “İmalat Sektörü İşletmelerinin Sermaye Yapısına Etki Eden Faktörlerin Analizi" başlıklı doktora tez çalışması temel oluşturmuştur.

\section{Önerilen Atıf/ SuggestedCitation}

Yücedağ Erdinç, N., Sayılgan, G. (2020).BİST İmalat Sektöründeki Küçük Boyuttaki ve Orta Ölçekteki İşletmelerin Sermaye Yapısına Etki Eden Faktörlerin Kanonik Korelasyon Analizi İle Karşılaştırmalı Olarak,İşletme Araştırmaları Dergisi, 12 (1), 826-847. 
Received 12 January 2020

Revised15 March 2020

Accepted20 March 2020

ArticleClassification:

Research Article
Quarterly data of firms are used in the analysis. In this paper, short term debt raito, long term debt ratio and total debt raito are used as dependent variables and profitability, firm size, liquidity, growth opportunity and tangibility as used firm-specific dependent variables and also GDP growth rate, interest rate and exchange rate as used macroeconomic dependent variables. As a method, canonical correlation analysis was preferred, so that firm-specific variables and macroeconomic variables wer eanalyzed simultaneously.

Findings - According to the results, total debt ratio is the most contributing leverage variables, while the liquidity is the most contributing firm-spesific variable, and there is a negative relationship between the leverage raitos. Exchange rate ratio is found to be the most contributing macroeconomicvariable and there is also a negative relaitonship between the leverage ratios.

Discussion - How businesses choose their capital structures and how macroeconomic factors affect their decision-making processes is one of the topics that the finance literature continues to work on. In this study, in which the capital structure determinants that are effective in the financial decision making process of firms are examined, it is determined that the small and medium scale manufacturing firms act in accordance with both Pecking Order Theory andTrade-off Theory at their capital structure decisions. Borrowing behavior of firms was generally similar to each other. When the literature is examined, studies using canonical correlation analysis were not found in the studies related to the factors affecting the capital structure decisions, and similar results were obtained with the studies conducted using other analysis methods.

\section{GİRiş̧}

Sermaye yapısı, işletmeninin özkaynak ve borçlarıyla kendini finanse etme şeklini ifade etmektedir. İşletmelerin nasıl bir sermaye yapısına sahip olması gerektiği karlılık, likidite, finansal risk ve borç ödeyebilme gücü gibi kriterlerleri dikkate alarak verilecek kararlarda önemli rol oynamaktadır. Çünkü verilecek olan kararlar işletmenin nihai hedefi olan firma değerini maksimize etme amacının yanı sıra, işletme sahip ve ortaklarının refahını da maksimize etmelidir. Diğer yandan işletmeye borç verenler ve potansiyel yatırımcılar için de işletmenin sermaye yapısı kararları önem arz etmektedir.

Sermaye yapısı teorileri, Modigliani ve Miller (1958)'in sermaye yapısının firma değeri üzerinde bir etkisinin olmadığına dair ortaya koyduğu çalışmasıyla sermaye yapısı üzerine uzun bir tartışmanın doğmasına neden olmuştur (Zein, 2016: 3). Daha sonra dengeleme teorisi, finansman hiyerarşisi teorisi, asimetrik bilgi teorisi, temsilcilik sorunu teorisi gibi birçok teori geliştirilmiş fakat evrensel olarak hemfikir olunan bir teori bulunamamıştır (Myers, 2001).

Sermaye yapısı kararları finans literatüründe sıkça araştırılan konulardan birisidir. Bu çalışmalardan bir kısmı sermaye yapısı kararlarını etkileyen işletmeye özgü (içsel-mikro) faktörlere ilişkindir (Harris ve Raviv, 1991; Rajan ve Zingales 1995; Deesomsak vd. 2004; Frank ve Goyal, 2009; Proença vd.;2014, Martin ve Saona; 2017). İçsel faktörler her ne kadar sermaye yapısı kararlarında etkili olsa da tek başına yeterli değildir. İşletmenin makroekonomik çevresi de sermaye yapısı kararlarına etki etmektedir. Gayri safi yurt içi hasıla oranı, enflasyon, faiz kararları, döviz kuru oranlarında meydana gelen değişmeler gibi işletmenin kontrolünde olmayan birçok faktör de karar verme sürecinde etkili olmaktadır. Gelişmekte olan ülke ekonomilerinden biri olan Türkiye'de de sermaye yapısına etki eden içsel faktörlere ilişkin çok sayıda çalışma yapılmış olmasına rağmen, hem işletmeye özgü hem de makroekonomik faktörleri dikkate alarak sermaye yapısı kararlarını inceleyen çalışma sayısı nispeten daha azdır. Çalışmada imalat sektörü işletmelerinin sermaye yapısı kararlarında etkili olan işletmeye özgü değişkenler ve makroekonomik değişkenler ile kaldıraç oranları arasındaki ilişkiler ayrı ayrı incelenmiş aynı zamanda işletmeye özgü değişkenler ile makroekonomik değişenler arasındaki ilişkiler de incelenerek aralarındaki benzerlik ve farklılıklar da ortaya konulmuştur. Literatür incelemesi sonucunda; işletmeye özgü ve makroekonomik değişkenlerin kaldıraç oranları üzerindeki etkisini araştıran çalışmalar olmakta birlikte, bu iki değişken setinin kendi arasındaki ilişkisini konu alan bir çalışma tespit edilememiştir. Bu kapsamda 2009-2017 yılları arasında Borsa İstanbul' da faaliyette bulunan ve verilerine kesintisiz olarak ulaşılan 134 işletme aktif büyüklüklerine göre gruplandırılmıştır. Yapılan sınıflandırma neticesinde 110 işletme, küçük ve orta büyüklükteki işletme olarak ele alınıp kanonik korelasyon yöntemiyle analiz edilmiştir. Kanonik korelasyon analizi, finans ve muhasebe alanlarında da kullanılan bir analiz yöntemi olmasına rağmen sermaye yapısı kararlarına ilişkin yapılan çalışmalarda çoğunlukla diğer çok değişkenli istatistiksel yöntemlerin kullanıldığı görülmüştür. 


\section{KAVRAMSAL ÇERÇEVE}

\subsection{Sermaye Yapısı Teorileri}

Modigliani ve Miller (1958)'in yaptığı çalışmalar ile sermaye yapısına ilişkin teorilerin temelleri atılmış ve dengeleme teorisi, finansman hiyerarşisi teorisi, asimetrik bilgi teorisi, temsilcilik sorunu teorisi gibi birçok teori geliştirilmiştir.

Sermaye yapısının seçimi konusunda evrensel olarak kabul görmüş bir teori olmasa da, literatürde en çok tartışlan iki teoriden biri dengeleme teorisi (trade-offtheory) diğeri ise finansman hiyerarşisi teorisidir (peckingordertheory) (Frank ve Goyal, 2009:1).Dengeleme teorisine göre, borç kullanımının yaratacağı vergi avantajı ve buna bağlı olarak temsil maliyetindeki azalmayla, borç kullanmadan kaynaklanan iflas ve sıkıntı maliyetleri arasında bir denge kurulması amaçlanmaktadır. Diğer yandan finansman hiyerarşisi teorisinde, dengeleme teorisinin aksine, optimal bir sermaye yapısından söz edilmemektedir. Teori, işletme yöneticileri ile diğer paydaşlar arasındaki bilgi asimetrisine dayanır. Myers ve Majluf (1984)'a göre finansman bir hiyerarşiyi takip etmektedir. İşletme öncelikli olarak içsel finansmanı diğer bir deyişle dağıtılmayan karlarını, daha sonra dış finansmanı en son olarak ise hisse senedi ihracı ile fon sağlamayı tercih edecektir (Buvanendra vd., 2016: 583). Sermaye artırımına gitmek işletme için yüksek derecede ters seçim problemine neden olurken, dış kaynakla finansman sağlama daha düşük derecede ters seçime neden olmaktadır (Frank ve Goyal, 2009: 6). Bu teoriler, kurumsal sermaye yapısının doğasını ve ayrıca potansiyel iç ve dış faktörleri tanımlamaya yardımcı olmaktadır (Buvanendra vd., 2016:583).

\subsection{Sermaye Yapısı Belirleyen Faktörler}

Sermaye yapısına etki eden faktörlere ilişkin yapılan çalışmaların büyük bir kısmı işletmeye özgü (içsel-mikro) faktörleri incelerken, bazı çalışmalarda ise işletmeye özgü faktörlere ek olarak makroekonomik faktörler de incelenmektedir. İşletme yöneticileri her ne kadar işletmeye özgü faktörleri kontrol edebilse de ülkeye özgü faktörler olan makroekonomik faktörler yöneticilerin kontrolünün ötesindedir. Özellikle gelişmekte olan ülke ekonomilerinde yapılan çalışmalarda bu faktörler zaman ve koşullara göre farklılık gösterdiğinden elde edilen sonuçlar da değişiklik gösterebilmektedir (Owolabi ve Inyang, 2013: 83).

\subsubsection{Sermaye Yapısına Etki Eden İşletmeye Özgü Faktörler}

İşletmeye özgü faktörler, işletmelerin sermaye yapısını belirlerken kullandıkları temel belirleyicilerdir. Konuyla ilgili yapılan çalışmalar incelendiğinde birçok araştırmada kullanılan belli başlı işletmeye özgü faktörler karlılık, varlık yapısı ve işletme büyüklügü olarak sıralanabilir (Vo, 2017: 107). Araştırmada işletme büyüklügüu, likidite, büyüme fırsatı, varlık yapısı, karlılık faktörleri analize dahil edilmiştir.

Dengeleme teorisine göre işletme büyüklügü ile kaldıraç arasında pozitif ilişki bulunmaktadır. Titman ve Wessels (1988), işletme büyüklügü ile borçlanma arasında pozitif bir ilişki olduğunu ortaya koymuştur. Büyük işletmeler küçük işletmelere göre daha düşük işlem maliyeti ile dişsal kaynaklardan yararlanmakta, borçlanma küçük işletmeler için daha zor olduğundan, dış kaynaklarla finansmandan uzak durmaktadırlar (Proença vd. 2014: 185). Aynı zamanda Rajan ve Zingales (1995) yaptıkları çalışmalarında işletme büyüklüğünün iflas riski ile ters orantılı olduğunu ve büyük işletmelerin asimetrik bilgi problemleriyle ilgili daha az sorun yaşadıklarını ve küçük işletmelere nazaran daha fazla bilgiyi kamu ile paylaştıklarını belirtmiştir. Bankalar da daha fazla çeşitlendirme yapabilen büyük işletmelere daha kolay imkanlarda fon kullandırma eğiliminde olduğundan, küçük işletmelere göre büyük işletmeler piyasadan daha fazla borç kullanma eğilimindedir (Martin ve Saona, 2017: 165). Finansman hiyerarşisi teorisine göre ise işletme büyüklüğü kaldıracı negatif etkilemektedir. Küçük işletmelerin finansal tablolarının kalitesi değişiklik gösterdiğinden, genellikle daha yüksek bilgi asimetrisiyle karşı karşıya kalmaktadırlar. Yatırımcılar işletmelerin finansal tablolarının denetlenmiş olmasını tercih ederken, küçük ölçekli işletmeler için bu kontrol mekanizması maliyetleri arttırmaktadır. Bu nedenle bu işletmeler kendi fonlarını kullanmayı, dış kaynakla finansman sağlamaya tercih edebilirler (Bas vd., 2009: 3).

İşletmelerin kısa vadeli borçlarını ödeyebilme gücünü gösteren likidite oranı daha yüksek olan işletmeler sözleşmeden doğan yükümlülüklerini zamanında yerine getirebildiğinden daha fazla borç kullanabilmektedir. Bu nedenle dengeleme teorisine göre kaldıraç ile likidite oranı arasında pozitif ilişki bulunmaktadır (Sheikh ve Wang, 2011: 123). Diğer yandan finansman hiyerarşisi teorisinde likidite ile kaldıraç 
negatif ilişkilidir. Likidite oranı yüksek olan işletmeler yeni yatırımlarını finanse etmek için içsel fonlarını kullanmayı tercih etmektedirler (Proença vd. 2014: 186).

Büyüme; finansal sıkıntı maliyetlerini artıran, nakit akış problemlerini azaltan ve borçlanmaya bağlı temsil sorununu ağırlaştıran bir unsurdur (Frank ve Goyal, 2009: 8). Dengeleme teorisine göre, büyüme kaldıraç oranını düşürür (Rajan ve Zingales, 1995; Ozkan, 2001; Bauer, 2004; Daskalakis ve Psillaki, 2008; Frank ve Goyal, 2009; Ata ve A $\breve{g}$, 2010; Akhtar vd., 2010). Büyüme fırsatları, sabit varlıklar gibi teminat gösterilebilir olmadığından iflas ya da finansal sıkıntı durumunda kolayca nakde çevrilememesi gibi nedenlerle büyüme fırsatı yüksek olan işletmeler duran varlıkları olan işletmelere nazaran daha az borç kullanmayı tercih ederler (Sayılgan ve Uysal, 2011: 111). Myers (1977), büyümeye yapılan yatırımların borcun temsil maliyetini artıracağını ve bu durumun dış kaynakla finansmanı azaltacağını ifade etmiştir (Proença vd., 2014: 186). Finansman hiyerarşisi teorisine göre ise büyüme fırsatları ile kaldıraç arasında pozitif ilişki bulunmaktadır. Büyüme fırsatı yüksek olan işletmeler daha fazla borç kullanmayı tercih etmektedir. Yatırım projelerini finanse etmek isteyen büyümekte olan işletmeler, diş kaynaklardan yararlanmak isteyebilir (Mokhova ve Zinecker, 2013: 2535). Literatürde büyüme fırsatları ile kaldıraç arasında pozitif ilişki bulan çalışmalar mevcuttur (Ross, 1977; Chen, 2007; Terim ve Kayalı, 2009; Okuyan ve Taşçı, 2010; Sayılgan ve Uysal, 2011; Akman, 2012; Ling veLi, 2013; Burucu ve Öndeş, 2016; Temimi vd., 2016; Zein, 2016; Matias ve Serrasqueiro, 2017).

Titman ve Wessels (1988) ve Harris ve Raviv (1991),maddi varlıkları fazla olan işletmelerin likiditesinin daha yüksek olacağını ve dolayısıyla daha fazla borçlanacağını belirtmektedir. Aynı zamanda duran varlıkları yüksek olan işletmeler göreceli olarak daha az finansal sıkıntı maliyetine katlandığından borç kapasiteleri daha fazla olmaktadır (Mokhova ve Zinecker, 2013: 2535). Dengeleme teorisi varlık yapısı ile kaldıraç kullanımı arasında pozitif ilişki olduğunu ileri sürmektedir. Diğer yandan finansman hiyerarşisi teorisine göre varlık yapısı ile kaldıraç arasında negatif ilişki bulunmaktadır. Sabit varlıklara ilişkin bilgi asimetrisinin az olması özsermayeyi daha az maliyetli k1lmaktadır. Boothvd, 2001; Acaravc1, 2004; Sayılgan vd., 2006; Huang ve Song, 2006; Demirhan, 2009; Elitaş ve Doğan, 2013; Serghiescu ve Vaidean, 2014; Cheng, 2014; Channar vd. 2015; Martin ve Saona,2017; Cansız ve Sayılgan, 2017 yaptıkları çalışmalarında varlık yapısı ile kaldıraç arasında negatif ilişki olduğunu tespit etmişlerdir.

Myers (1984)'e göre finansman kaynakları ile ilgili karar verirken işletmeler, öncelikle dağıtılmamış karlarını kullanmayı daha sonra borç kullanımını en son olarak ise yeni hisse ihracını tercih ederler. Dolayısıyla karlı işletmeler yatırımlarında, içsel fonlarını diğer bir deyişle dağıtılmayan karlarını kullanarak daha az borçla finansmanı tercih ederler (Mokhova ve Zinecker, 2013: 2536).Finansman hiyerarşisi teorisi karlılık ile kaldıraç arasında negatif ilişki olduğunu ileri sürmektedir. Diğer yandan dengeleme teorisine göre kaldıraç, karlılık ile pozitif ilişkilidir. Karlı işletmeler daha düşük iflas riskine sahip olduklarından borç maliyetleri daha az olmakta böylece daha yüksek kaldıraç oranına sahip olmaları beklenmektedir (Merika vd., 2015: 94). Bunun sonucunda işletmeler vergi avantajından ve faiz indiriminden daha çok yararlanabilecektir (Cheng, 2014; 20). Literatüre bakıldığında karlılık ile borç düzeyi arasındaki ilişkide herhangi bir fikir birliği sağlanamadığı görülse de yapılan ampirik çalışmalarda çoğunlukla kaldıraç ile karlılık arasında negatif ilişki bulunmuştur. Mazur 2007, Köksal vd. 2013 ve Serghiescu ve Vaidean, 2014).Titman ve Wessels, 1988; Harris ve Raviv, 1991; Rajan ve Zingales, 1995, Özkan, 2001; Bauer, 2004; Daskalakis ve Psillaki, 2008; Bopkin, 2009; Dincergok ve Yalcıner, 2011; Nguyen ve Wu, 2011 yaptıkları çalışmalarda negatif bir ilişki olduğunu belirtmiştir (Akt: Mokhova ve Zinecker,2013: 2534; Acaravc1, 2015: 16).

\subsubsection{Sermaye Yapısına Etki Eden Makroekonomik Faktörler}

İşletmeye özgü faktörler olarak adlandırılan içsel faktörler büyük ölçüde analiz edilmiş olsa da dışsal faktörler nispeten literatürde daha az konu olmuştur (Booth vd., 2001; De Jong vd., 2008; Muthama vd., 2013). İşletme yöneticilerinin kontrolü dışında yer alan ve sermaye yapısı kararlarında etkili olan GSYİH büyüme oranı, faiz oranı, döviz kurunda yaşanan değişmeler, ülkelerin siyasi riskleri, bankacılık sektöründeki gelişmeler, enflasyon oranı gibi birçok makroekonomik faktörler bulunmaktadır. Bu çalışmada GSYİH büyüme oranı, faiz oranı ve döviz kuru oranı makroekonomik faktörler olarak ele alınmıştır.

GSYİH, belirli bir dönemi kapsayan, o ülke sınırları içerisinde üretilen nihai mal ve hizmetlerin parasal karşılığını gösteren bir göstergedir ve fiyatlar genel seviyesindeki ve üretim miktarındaki değişimlerden etkilenebilir. Bir ülke ekonomisi büyüdükçe, ülkedeki işletmeler de yatırımlarını finanse edebilmek için gerek 


\section{N. Yücedağ Erdinç - G. Sayılgan 12/1 (2020) 826-847}

duyulan kaynak miktarını artırabilecektir. Böylece artan kaynak ile işletme daha fazla yatırım yapabilecek ve karlılığı da artacaktır. Büyümede yaşanan artış aynı zamanda hisse senedi piyasalarının da gelişmesini sağlayarak, işletmelerin farklı kaynaklardan yabancı kaynak bulmalarını sağlayacaktır. İşletmelerin yatırımlarında kullanacağı sermaye ihtiyacı artacağı için GSYİH büyüme oranının işletmelerin borç kullanımına pozitif etki etmesi beklenmektedir (Dinçergök, 2010: 88). Öte yandan Demirgüç-Kunt ve Maksimoviç (1995) büyüme oranları ve kaldıraç oranları arasında önemli negatif ilişki saptamışlardır (Demirgüç-Kunt, Maksimoviç, 1995: 18). Booth, vd. (2001) gelişmişve gelişmekte olan ülkeler üzerinde yaptıklarıçalışmalarında kaldıraç oranının durgunluk dönemlerinde artarken genişleme dönemlerindeazaldığını belirtmiştir. Gajurel (2006), 1995-2004 yılları arasında GSYİH büyüme oranı, enflasyon ve sermaye piyasalarının gelişmişlik düzeyinin Nepal'deki işletmelerin sermaye yapıları üzerindeki etkilerini incelediği çalışmasında, GSYİH büyüme oranının, toplam borçlar ve kısa vadeli borçlar kullanılarak hesaplanan kaldıraç oranları üzerinde negatif etkiye sahip olurken, uzun vadeli borçlar kullanılarak hesaplanan kaldıraç üzerinde pozitif etkiye sahip olduğunu ortaya koymuşlardır. Yüksek ekonomik büyüme işletmelerin daha fazla uzun vadeli borç kullanırken, daha az kısa vadeli borç kullanmasına neden olmaktadır. (Gajurel, 2006: 6-7).

Faiz, borç finansmanın maliyetidir ve faiz oranlarındaki artış genellikle borç kullanımında düşüşe yol açacaktır (Zein, 2016: 7). Sermaye maliyeti üzerinde etkili olan faiz oranı, işletmelerin sermaye yapısı kararlarını da etkilemektedir. İşletmeler kullandıkları borcun faizini vergi avantajından yararlanarak vergiden düşerler. Fakat yüksek faiz oranı, işletmelerin ortalama sermaye maliyetini arttıracağından kredi faiz oranı yüksek olduğunda, işletmeler borçlanmayı tercih etmezler. Borç faiz yükümlülüğü yüksek olan işletmelerin iflas olasılı̆̆ı da yüksek olacağından işletmeler sermaye yapısını belirlerken piyasa faiz oranını, hem vade hem de faiz oranı bakımından göz önünde bulundurmalıdır. Demirguc- Kunt ve Maksimovic (1996) yaptıkları çalışmalarında analiz ettikleri ülkelerde kredi faiz oranı ile kaldıraç arasında ters yönlü ilişki olduğunu ileri sürmüşlerdir. Dincergok ve Yalcıner (2001) faiz oranı ve sermaye yapısı arasında ters yönde bir ilişki olduğunu belirtmiştir. Buna karşın Bokpin (2009)'e göre, faiz oranı kurumsal sermaye yapısını pozitif ve anlamlı şekilde etkilemektedir.

Döviz kurlarında ve kambiyo piyasalarında meydana gelen gelişmeler yerel para veya yabancı para ile borçlanma konusunda işletmelerin tercihlerini etkilemektedir (Akgüç, 1998, 506).İşletmelerin yabanc1 para cinsinden borcu yüksekse, yerel parada meydana gelen değer kaybı sektörler açısından daraltıcı bir etki yaratacaktır. Yerel para değer kazandığında ise yabancı para cinsinden borçlu olan işletmelerin yatırımları artarken, yerel paranın değer kaybettiği dönemlerde azalmakta, işletmelerin borç yükü artarken, net servetleri ise azalmaktadır. Net servet değerinde meydana gelen azalış ise yatırımları olumsuz yönde etkilemektedir (Taşseven ve Çınar, 2015: 128). Uluslararası döviz kuru dalgalanmalarına maruz kalma riskini azaltmak için ihracat ve/veya ithalat yapan, uluslararası sermaye piyasalarına ulaşabilen işletmeler döviz kurlarındaki dalgalanmalardan etkilendiğinden, döviz kurunda yaşanan gelişmeler işletmelerin sermaye yapısına ilişkin kararları ve kaldıraç kullanımını etkilemektedir. Çalışmada döviz kuru değişkenin analize dahil edilmesi bu nedenle önemlidir.

\subsection{Literatür Taraması}

Titman ve Wessel (1988), 1974-1982 dönemini kapsayan çalışmalarında 469 işletmenin sermaye yapisı kararlarına etki eden faktörleri incelemiş, araştırma sonuçlarına göre, işletme büyüklüğü ile kısa vadeli kaldıraç arasında negatif ilişki olduğu, borç dışı vergi kalkanı, kazançların değişkenliği, büyüme fırsatları ve maddi duran varlıklar ile kaldıraç arasında ise istatistiksel olarak anlamlı bir ilişki olmadığı tespit edilmiştir.

Harris ve Raviv (1991), temsilcilik maliyeti, asimetrik bilgi, ürün/çıktı piyasa etkileşimi ve kurumsal kontrol karşılıkları gibi sermaye yapısı teorilerini incelemişlerdir. Araştırma sonuçlarına göre, işletmelerin kaldıraç oranı ile maddi duran varlıklar, borç dışı vergi kalkanı, büyüme fırsatları ve işletme büyüklügü ile aynı yönde bir ilişki olduğunu, kazançların değişkenliği, reklam ve pazarlama giderleri, iflas olasılığı ile kaldıraç oranı arasında ise ters yönde ilişkili olduğu saptanmıştır.

Rajan ve Zingales (1995), 1987-1991 yıllarını kapsayan G-7 ülkelerinde faaliyette bulunan 2583 işletmenin finansal verilerini kullanarak işletmelerin sermaye yapısının belirleyicilerini ortaya koymaya çalışmışlardır. Kaldıraç oranları ile piyasa değeri/defter değeri oranı, varlık yapısı, karlılık, işletme büyüklüğü arasındaki ilişkiyi incelemişlerdir. Araştırmada G-7 ülkeleri arasında anlamlı farklılıklar tespit edilmemiş, işletme 
büyüklüğü, maddi duran varlık yapısı kaldıraç ile aynı yönde, piyasa değeri/defter değeri oranı ve kârlılık kaldıraç oranı ile ters yönde ilişkili bulunmuştur.

Booth vd. (2001) 1980-1991 dönemini kapsayan çalışmasında gelişmekte olan ülkelerdeki sermaye yapısı kararlarının trendini ve sermaye yapısını belirleyen faktörleri araştırmışlar, gelişmiş ülkeler ile anlamlı bir farklılık olup olmadığını incelemişlerdir. Tüm gelişmekte olan ülkeler açısından karlılık ve kaldıraç oranı arasındaki ilişki yüksek derecede anlamlı ve negatif iken, gelişmiş ülkelerde ilişkinin pozitif olması çalışmanın en dikkate değer bulgusudur.

Sayılgan vd. (2006), İMKB' de işlem gören 123 imalat işletmesinin 1993-2002 yılları arasında kurumsal sermaye yapısını etkileyen içsel değişkenleri araştırmışlardır. Panel veri analizi kullanılan çalışmada kaldıraç oranı ile işletme büyüklüğü ve toplam varlıklardaki büyüme fırsatları değişkenleri arasında aynı yönlü; karlılık, duran varlıkların büyüme fırsatları, borç dışı vergi kalkanı ve duran varlık yapısı değişkenleri ile kaldıraç arasında ise ters yönlü ilişki bulunmuştur.

Drobetz vd. (2007), işletmelerin zamanla değişen sermaye yapısı belirleyicilerini araştırmak için 1983-2002 yılları arasında 706 Avrupa işletmesine ait verileri kullanarak hedef kaldıraç oranına ulaşmak için işletmeye özgü ve makroekonomik değişkenleri analiz etmişlerdir. Çalışmada, varlık yapısı ve işletme büyüklügünün kaldıracı aynı yönde, borç dışı vergi kalkanının kaldıracı ters yönde etkilemesi ödünleşme teorisi ile uyumlu olduğunu göstermiştir. Büyüme fırsatlarının kaldıracı aynı yönde etkilediği saptanmıştır. Kısa vadeli faiz oranı ile sermaye yapısı ayarlama hızı arasında negatif bir ilişki tespit edilmişken, kredi marjı, hazine bonosuEurodolar farkı ile sermaye yapısı ayarlama hızı arasında istatistiksel olarak anlamlı bir ilişki bulunamamıştır.

Frank ve Goyal (2009), 1950-2003 döneminde ABD'de halka açık işletmelerin verilerini kullanarak sermaye yapısına etki eden faktörleri belirlemeye çalışmıştır. Uzun bir zaman serisi ile yapılan çalışmada çekirdek kaldıraç modeli olarak tanımladıkları modelde işletmeye özgü faktörlerden varlık yapısı, işletme büyüklüğü, büyüme fırsatları, karlılık, sektörel faktör olarak kaldıraç ortalaması ve makro değişken olarak enflasyon oranının kaldıracı en iyi anlatan faktörler olduğu sonucuna ulaşmışlardır. Araştırmaya göre varlık yapısı ve işletme büyüklügü kaldıracı aynı yönde etkilerken; büyüme fırsatları ve karlılık ile kaldıraç oranı arasında ters yönlü ilişki olduğu tespit edilmiş, işletmelerin sermaye yapılarının ödünleşme teorisini destekler nitelikte olduğu saptanmıştır.

Okuyan ve Taşcı (2010) Türkiye'deki sanayii işletmelerinin sermaye yapısını etkileyen faktörleri ve sermaye yapısı kararlarında ödünleşme teorisi ile finansman hiyerarşisi teorisinden hangisinin daha etkili olduğunu araştırdıkları çalışmasında 1993-2007 yılları arasında İstanbul Sanayi Odası tarafından her yıl belirlenen 500 büyük ve ikinci 500 büyük olmak üzere toplam 1000 sanayi işletmesi panel veri analizi ile incelenmiştir. Araştırma sonuçlarına göre, işletme büyüklüğü ve karlılık değişkenlerinin borç kullanımı üzerinde ters yönde ve anlamlı ilişkisinin finansman hiyerarşisini destekler nitelikte olduğunu saptanmış, Türkiye'deki sanayi işletmeleri finansman hiyerarşisi teorisini destekledikleri tespit edilmiştir.

Sayılgan ve Uysal (2011), 1996-2008 yılları arasında Türkiye Cumhuriyet Merkez Bankası bilançolarından yararlanarak elde ettikleri sektör bilançoları ile sermaye yapısını etkileyen faktörleri incelemiştir. Bulgulara göre, varlık yapısı, karlılık ve büyüklük borçlanmayı aynı yönde; borç dışı vergi kalkanı ise ters yönde etkilemektedir. Elde edilen sonuçlar ödünleşme teorisini desteklemekte sadece büyüme fırsatlarının borçlanma üzerindeki aynı yönlü etkisi finansman hiyerarşisi teorisini desteklemektedir.

Proença vd. (2014), Portekiz' de KOBİlerin sermaye yapısına etki eden faktörleri araştırmış, 2007-2010 dönemi içerisinde $12.857 \mathrm{KOBI}^{\prime}$ ye ait veri Amadeus veri tabanından elde edilmiştir. Araştırma sonuçlarına göre, likidite, varlık yapısı ve karlılık değişkenleri işletmelerin sermaye yapısı kararlarında en fazla etkiye sahip olan değişkenlerdir. Karlılık ile borçlanma oranları arasındaki negatif ilişkiye göre Portekiz'de KOBİlerin yatırımların finanse etmek için riskten kaçınmak amacıyla öncelikle içsel kaynakları tercih ettikleri daha sonra diş kaynaklara yöneldiklerini göstermekte ve bu sonuç finansman hiyerarşisi teorisini desteklemektedir.

Matias ve Serrasqueiro (2017), Portekiz'in farklı bölgelerindeki KOBİlerin sermaye yapısına etki eden işletmeye özgü faktörleri araştırmışlardır. 2007-2011 yılları arasında 11.016 KOBİ, karlılık, işletme büyüklügü̈, varlık yapısı, işletme yaşı ve büyüme fırsatları değişkenleri kullanılarak analiz edilmiştir. Bağımlı değişkenler toplam borç oranı, orta ve uzun vadeli borç oranı ve kısa vadeli borç oranı olarak analize dahil edilmiştir. Araştırma sonuçlarına göre, büyüklük KOBI'ler için önemli bir değişken olurken karlılık ve borç oranları 
arasında bulunan negatif ilişki finansman hiyerarşisi teorisini desteklemektedir. Karlılık ve varlık yapısı toplam borcu açıklayan en iyi değişkenler olarak tespit edilmiş, büyüme fırsatları ve borç oranları arasında pozitif bir ilişki olduğu saptanmıştır.

Daskalakis vd. (2017) makro ekonomik koşullar değiştiğinde Yunanistan'daki KOBílerin işletmeye özgü sermaye yapısı belirleyicileri ile makroekonomik değişkenlerin göreceli önemini araştırdığı çalışmasında Genelleştirilmiş momentler tahmin metodu ile (Generalized method of moment - GMM) 2004-2014 yılları arasında 17.317 KOBİ'yi incelemiştir. Makroekonomik değişkenlerden kredi genişlemesi ile kaldıraç oranları arasında pozitif bir ilişki varken, enflasyon ile kaldıraç arasında bir anlamlı bir ilişki bulunamamış, faiz oranları ile kriz öncesi daha güçsüz ve negatif bir ilişki, kriz süresince ise güçlü pozitif bir ilişki tespit edilmiştir. İçsel değişkenlerden varlık yapısı ve nakit zengini işletmeler hariç diğer tüm değişkenler arasında önemli olmayan ya da sabit olmayan bir ilişki saptanmıştır.

\section{VERİ SETİ VE YÖNTEM}

Çalışmada kullanılan veriler 2009-2017 yılları arasında Borsa İstanbul'da faaliyette bulunan imalat işletmelerinin finansal durum tablosu ve gelir tablosu verilerinden elde edilmiş olup üçer aylık veriler kullanılmıştır. 2018 ve 2019 yıllarına ilişkin finansal tablolarda yer alan farklılıklar nedeniyle kayıp verileri önlemek amacıyla zaman periyodu 9 yıllık veri ile kısıtlı tutulmuştur. Kamuyu Aydınlatma Platformu ve Borsa İstanbul resmi web sitelerinden yararlanılarak türetilen değişkenler SPSS programı yardımıyla analiz edilmiştir. İşletmelerin makroekonomik faktörlerini belirlemeye yönelik olarak seçilen değişkenlere ilişkin 36 çeyrek döneme ait veriler TCMB web sitesinden elde edilmiştir. İlgili dönemde verilerine kesintisiz ulaşılan 134 işletme aktif büyüklüklerine göre büyük, orta ve küçük ölçekli işletmeler olarak gruplandırılıp imalat sektörü işletmelerinin sermaye yapısına etki eden işletmeye özgü ve makroekonomik faktörlerin işletmelerin sermaye yapısı kararlarında hangi faktörlerin katkısının ne kadar olduğunun hem ayrı ayrı hem de içsel ve dışsal değişkenler birlikte analiz edilmesi amaçlanmıştır.Çalışmada işletmeler, Türkiye AB uyum yasaları yönetmeliğine göre, çalışan sayısı 10'dan az veyıllık net satış hasılatı veya mali bilançosundan herhangi biri 3 milyon Türk Lirasını aşmayan işletmeler mikro, çalışan sayısı 50 kişiden az ve yıllık net satış hasılatı veya mali bilançosundan herhangi biri 25 milyon Türk Lirasını aşmayan işletmeler küçük işletme, çalışan sayısı 250 kişiden az ve yıllık net satış hasılatı veya mali bilançosundan herhangi biri 125 milyon Türk Lirasını aşmayan işletmeler orta büyüklükteki işletmeler, çalışan sayısı 250'den fazla olan işletmeler ise büyük ölçekli işletmeler olacak şekilde gruplandırılmıştır (www.kosgeb.gov.tr; 2018). Sadece personel sayısı dikkate alınarak yapılan KOBİ tanımlaması eksik kalmaktadır. Çünkü sadece personel sayısı esas alındığında KOBİ kapsamına alınabilecek işletmeler toplam satışlar ya da toplam aktif büyüklüğüne göre büyük işletme gibi davranabilmektedir (Müslümov, 2001: 220). Çalışmada aktif büyüklüklerin yoğunlaştı̆̆ı aralıklar göz önünde bulundurularak yapılan gruplandırma neticesinde 110 işletme, küçük ölçekli ve orta ölçekli işletme olarak belirlenmiş ve buişletmelerin sermaye yapısı kararları ile ilişkisi karşılaştırmalı olarak incelenmiştir. Farklı aktif grupların oluşturulması değişkenler arasındaki ilişkinin nasıl şekillendiğini ortaya koymayı amaçlamıştır.

Tablo 1. Çalışma Kapsamında Kullanılan Değişkenler

\begin{tabular}{|l|l|}
\hline Bağımlı Değişkenler (Kaldıraç oranları) & Tanım \\
\hline Kısa vadeli borç oranı (STDR) & KVYV/Toplam Varlıklar \\
\hline Uzun vadeli borç oranı (LTDR) & UVYK/ Toplam Varlıklar \\
\hline Toplam Borç Oranı (TDR) & Toplam Borçlar /Toplam Varlıklar \\
\hline Bağımsız Değişkenler (İçsel-işletmeye özgü) & Tanım \\
\hline İşletme Büyüklüğ̈u (Size) & Toplam varlıkların Logaritması \\
\hline Varlık Yapısı (Tangibility) & Duran Varlıklar/ Toplam Varlıklar \\
\hline Büyüme Fırsatları (GrowthOpportunity) & Toplam varlıklardaki yüzde değişım \\
\hline Karlılık (EBIT) & $\begin{array}{l}\text { Faaliyet Karı (Faiz ve Vergi Öncesi Kar)/ Toplam } \\
\text { Varlıklar }\end{array}$ \\
\hline Likidite & Dönen Varlıklar/ KVYK \\
\hline
\end{tabular}


N. Yücedağ Erdinç - G. Sayılgan 12/1 (2020) 826-847

\begin{tabular}{|l|l|}
\hline Bağımsız Değişkenler (Dışsal- Makroekonomik) & Tanım \\
\hline GSYïH büyüme oranı & $\begin{array}{l}\text { Cari yıldaki GSYİH ile önceki yıldaki GSYİH } \\
\text { arasındaki fark (log) }\end{array}$ \\
\hline Faiz oranı & $\begin{array}{l}\text { Bankalarca açlan kredilere uygulanan ağırlıklı } \\
\text { ort. Faiz oranı (TL-Ticari) }\end{array}$ \\
\hline Döviz kuru & TÜFE bazlı reel efektif döviz kuru oranı \\
\hline
\end{tabular}

\subsection{Kanonik Korelasyon Analizi Tanımı}

Kanonik korelasyon analizi ilk kez Hotteling tarafından (1935) tanımlanmış olan iki veya daha fazla değişken içeren iki değişken seti arasındaki ilişkiyi doğrusal bileşenler aracılığıyla değerlendiren, her iki değişken setinin orijinal değişkenlerinin birim varyanslı ve maksimum korelasyonlu bileşimlerini elde ederek analiz eden çok değişkenli bir istatistiksel yöntemdir (Kalaycı, 2010: 237). Bağımlı ve bağımsız değişkenler için hem metrik hem de metrik olmayan veriler kullanılabilir (Hair vd., 1998: 443).Genel kullanımı aşağıdaki gibi gösterilebilir;

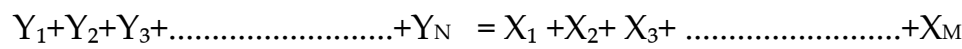

(metrik ya da metrik olmayan $)=($ metrik ya da metrik olmayan)

Kanonik korelasyon analizinde oluşturulabilecek maksimum kanonik değişken sayısı, hangi değişken setinde daha az sayıda değişken varsa o setteki değişken sayısına eşittir. Her bir kanonik değişken çifti (kanonik fonksiyon) birbirinden bağımsızdır. Bu nedenle her bir fonksiyon bağımlı ve bağımsız değişken setleri arasında bulunan farklı ilişkileri temsil eder (Okeke ve Okeke, 2016: 15). Araştırmacı istatistiksel olarak anlamlı bulunan her bir kanonik fonksiyonu yorumlayabilir. Değişken kümeleri arasındaki ilişkinin kanonik değişkenlere dönüştürülüp bu şekilde analiz edilmesi durumu aslında bir boyut indirgeme olarak ifade edilebilir. Bunun nedeni $p$ adet $X$ (bağımsız) ve $q$ adet $Y$ (bağımlı) değişken arasındaki pxq adet korelasyon yerine değişkenlerin doğrusal kombinasyonu olan daha az sayıdaki kanonik değişkenlerin korelasyonunun incelenmesidir (Ekizler, 2016: 41). Kanonik korelasyon analizi sebep-sonuç ilişkilerini tanımlamak için uygun bir yöntem olmasa da iki değişken grubu için genel bir yorum yapmak adına etkili bir araçtır.Bu sayede kümelerdeki karşılıklı ilişkiler incelenirken, değişken kümesinin kendi içindeki her bir değişken arasındaki ilişkiler için de açıklama yapılabilir (Jang vd., 2008: 480). Çoklu regresyon analizinde tek bir bağımlı (metrik) değişkenle $(\mathrm{Y})$, iki veya daha fazla bağımsız değişken $\left(\mathrm{X}_{1}, \mathrm{X}_{2}, \ldots . . . \mathrm{X}_{\mathrm{P}}\right)$ arasındaki ilişkiyi araştırırken, kanonik korelasyon çoklu bağımsız değişkenlerden çoklu bağımlı değişkenleri eşzamanlı olarak tahmin eder (Hair vd., 2010:241). Kanonik korelasyon analizinde, bağımlı değişken setinde birden fazla değişkenden oluşan yeni bir değişken oluşmakta (kanonik değişken) ve iki veri seti arasındaki çok boyutlu ilişkiler birkaç çift kanonik değişken arasındaki ilişkiye indirgenmiş olmaktadır. Hem metrik hem de metrik olmayan veriler kullanılabilen bir yöntem olması, kanonik korelasyonun araştırmacıya sağladığı faydalardan biridir. Çalışmada birden fazla bağımlı değişken olması ve işletmeye özgü değişkenler ile makroekonomik değişkenlerin işletmelerin finansman kararlarında katkısının ne kadar olduğunun eşzamanlı olarak analiz edilebilmesi çalışmada kanonik korelasyon analizi yönteminin kullanılma nedenleri olarak sayılabilir.

\subsubsection{Kanonik Korelasyonların Anlamlılık Testi}

Kanonik korelasyonlar hesaplandıktan sonra yorumlanabilmesi için anlamlı olan kanonik korelasyon fonksiyonlarının belirlenmesi gerekmektedir. Bunun için Bartlett'inWilks' Lambda Testi, Pillsi Testi, LawleyHotelling Testi, Roy'un En Büyük Özdeğer Testi gibi uygulanan anlamlılık testleri bulunmaktadır. Bu çalışmada Wilks' Lambda Testi esas alınacaktır. Sonuçlar, standardize edilmiş katsayılar (canonical weights), kanonik yük (canonical loadings), kanonik çapraz yük (canonical cross loadings), açıklanan varyans oranı ve gereksizlik indeksi (redundancy index) yardımıyla yorumlanabilir (Hair vd. 1998: 453).

Açıklanan varyans oranı; bağımlı veya bağımsız değişken kümesindeki kanonik değişkenlerin, ilgili kümedeki (bağımlı veya bağımsız) değişkenlerde açıkladığı kısmı göstermektedir ve ilgili kümedeki her bir kanonik değişkene ait kanonik yüklerin karelerinin ortalamasıdır (Bolat, 2004: 89). Gereksizlik indeksi, kanonik bağımlı ve bağımsız değişken kümesinin diğer kümenin kanonik değişkeni tarafından açıklanan varyansının ortalamasını vermektedir (Ekizler, 2016: 126). 


\subsubsection{Kanonik Ağırlıklar (CanonicalWeight)}

Kanonik değişkenlerdeki katsayıların ve bunların işaretlerinin incelenmesi değişkenlerin fonksiyona ne yönde ve göreceli olarak ne ölçüde katkıda bulunduklarını gösterir. Göreceli olarak daha fazla ağırlığa sahip olan değişkenlerin kanonik değişkene katkısı daha fazla olmaktadır (Hair vd., 1998:453). Analizlerde kanonik ağırlıkların kullanılması yüksek derecede çoklu doğrusal bağlantı olması durumunda büyük farklılıklar göstermektedir (Hair vd., 1998:453). Bu nedenle kanonik fonksiyonlar yorumlanırken katsayılar yerine kanonik yükler tercih edilmektedir.

\subsubsection{Kanonik Yükler (Canonical Loadings) ve Kanonik Çapraz Yükler (Canonical Cross Loadings)}

Kanonik yükler, bağımlı ya da bağımsız değişken setinde gözlemlenen orijinal değişkenlerin her biri ile setin kanonik değişkeni arasındaki basit doğrusal korelasyonu ölçer (Hair vd.,1998: 453). Orijinal değişkene ait kanonik çapraz yük ise; bu değişkenin kendisine ait kanonik değişken ile ne kadar ilişkili olduğuna ek olarak kendi kanonik değişkeninin diğer kanonik değişkenle olan ilişkisini de içermektedir (Ekizler, 2016: 60). Kanonik çapraz yükler kanonik yüklerde yer alan bir ara adımı ortadan kaldırarak bağımlı ve bağımsız değişken ilişkilerinin daha doğrudan ölçümünü sağlanmaktadır. Kanonik korelasyon analizi yapılırken araştırmacıların kanonik çapraz yükleri kullanması tercih edilir (Hair vd. 1998: 454).

\section{SONUÇLAR}

\subsection{Korelasyon Analizi Sonuçları}

Tablo 2'de küçük ölçekli işletmelere ilişkin Pearson korelasyon analizi sonuçları yer almaktadır. Buna göre kaldıraç oranları ile işletmeye özgü değişkenler içerisinde en yüksek korelasyona katsayısına sahip olan likidite değişkeni $(-0,9353)$ iken, makroekonomik faktörler içerisinde en yüksek korelasyona sahip olan döviz kuru $(0,8955)$ oranıdır. İşletmeye özgü değişkenler ile makroekonomik değişkenler arasındaki korelasyona bakıldığında ise işletme büyüklügü ile GSYİH oranı arasında oldukça yüksek $(0,9768)$ pozitif yönlü bir ilişki olduğu tespit edilmiştir. Buna göre ekonomik büyüme ile işletmelerin büyüklüğünde ve karlılığında yaşanan artış işletmelerin likidite konusunda sıkıntıya düşmeyeceğini işaret edebilir.

Tablo 2. Küçük Ölçekli işletmelerin Korelasyon Matrisi

\begin{tabular}{|c|c|c|c|c|c|c|c|c|c|c|c|}
\hline & Likidite & Büyüklük & $\begin{array}{l}\text { Varllkk } \\
\text { yapis1 }\end{array}$ & Karlilik & $\begin{array}{l}\text { Büyüme } \\
\text { firsatlar1 }\end{array}$ & $\begin{array}{ll}\text { Döviz } \\
\text { oran1 }\end{array}$ & Faiz oranı & $\begin{array}{l}\text { GSYIH } \\
\text { oran1 }\end{array}$ & $\begin{array}{l}\text { Kısa vadeli } \\
\text { borç oran1 }\end{array}$ & $\begin{array}{l}\text { Uzun vadeli } \\
\text { borç oranı }\end{array}$ & $\begin{array}{l}\text { Toplam borç } \\
\text { oranı }\end{array}$ \\
\hline Likidite & 1,0000 &,- 6950 &,- 2451 &,- 5826 &,- 4555 & 6071 & $\begin{array}{l}-, 4259 \\
\end{array}$ &,- 6494 &,- 2484 &,- 2562 &,- 5630 \\
\hline Büyüklük & & 1,0000 & 0211 &, 7614 & .4730 & -8718 & .5515 & 9665 &,- 0350 & ,4902 &, 3278 \\
\hline $\begin{array}{l}\text { Varluk } \\
\text { yapisi }\end{array}$ & & & 1,0000 &,- 2541 &,- 0111 &, 1445 & .0127 &,- 0675 & .1435 &,- 1510 &, 1350 \\
\hline Karllilk & & & & 1,0000 & .4430 & -.7439 &, 3465 &, 7268 &,- 0839 &, 4666 &, 2355 \\
\hline $\begin{array}{l}\text { Büyüme } \\
\text { firsatları }\end{array}$ & & & & & 1,0000 &,- 4563 & .0509 & .4040 &,- 0613 & .1731 &, 0735 \\
\hline $\begin{array}{l}\text { Döviz } \\
\text { kuru } \\
\text { orran1 }\end{array}$ & & & & & & 1,0000 &,- 6754 &,- 8278 &, 0381 &,- 4979 &,- 3296 \\
\hline $\begin{array}{l}\text { Faiz } \\
\text { oran1 }\end{array}$ & & & & & & & 1,0000 & ,4591 &,- 0211 & 3747 & 2448 \\
\hline $\begin{array}{l}\text { GSYIH } \\
\text { oran1 }\end{array}$ & & & & & & & & 1,0000 &, 0321 & ,4407 &, 3781 \\
\hline $\begin{array}{l}\text { Kisa } \\
\text { vadeli } \\
\text { borç } \\
\text { oranı }\end{array}$ & & & & & & & & & 1,0000 &,- 7060 &, 8516 \\
\hline $\begin{array}{l}\text { Uzum } \\
\text { vadeli } \\
\text { borç } \\
\text { oranı }\end{array}$ & & & & & & & & & & 1,0000 &,- 2371 \\
\hline $\begin{array}{l}\text { Toplam } \\
\text { borc } \\
\text { orant }\end{array}$ & & & & & & & & & & & 1,0000 \\
\hline
\end{tabular}

Tablo 3'de ise orta ölçekli işletmelere ilişkin Pearson korelasyon analizi sonuçları yer almaktadır. Buna göre kaldıraç oranları ile işletmeye özgü değişkenler içerisinde en yüksek korelasyona katsayısına sahip olan likidite değişkeni $(-0,5630)$ iken, makroekonomik faktörler içerisinde en yüksek korelasyona sahip olan döviz kuru $(0,4979)$ oranıdır. İşletmeye özgü değişkenler ile makroekonomik değişkenler arasındaki korelasyona bakıldığında ise işletme büyüklüğü ile GSYİH oranı arasında oldukça yüksek $(0,9665)$ pozitif yönlü bir ilişki olduğu tespit edilmiştir. Küçük ölçekli işletmelere benzer şekilde ortaya çıkan bu pozitif ilişkiye göre, ekonomide yaşanan iyimserlik, işletmelerin büyümesini ve finans kaynaklarına erişimini kolaylaştırmakta aynı zamanda karlılığını da artırmaktadır. 
N. Yücedağ Erdinç - G. Sayılgan 12/1 (2020) 826-847

Tablo 3. OrtaÖlçekli işletmelerin Korelasyon Matrisi

\begin{tabular}{|c|c|c|c|c|c|c|c|c|c|c|c|}
\hline & Likidite & Büyüklük & $\begin{array}{l}\text { Varlik } \\
\text { yapis1 }\end{array}$ & Karlilık & $\begin{array}{l}\text { Büyüme } \\
\text { firsatlar1 }\end{array}$ & $\begin{array}{ll}\begin{array}{l}\text { Döviz kuru } \\
\text { oranı }\end{array} & \\
\end{array}$ & Faiz oran1 & $\begin{array}{l}\text { GSYIH } \\
\text { orani }\end{array}$ & $\begin{array}{l}\text { Kisa vadeli } \\
\text { borç oranı }\end{array}$ & $\begin{array}{l}\text { Uzun vadeli } \\
\text { borç oranı }\end{array}$ & $\begin{array}{l}\text { Toplam borç } \\
\text { oranı }\end{array}$ \\
\hline Likidite & 1,0000 &,- 6950 &,- 2451 &,- 5826 &,- 4555 & 6071 &,- 4259 &,- 6494 &,- 2484 &,- 2562 &,- 5630 \\
\hline Büyüklük & & 1,0000 &, 0211 & .7614 & 4730 &,- 8718 &, 5515 & 9665 &,- 0350 & 4902 & 3278 \\
\hline $\begin{array}{l}\text { Varlik } \\
\text { yapis1 }\end{array}$ & & & 1,0000 &,- 2541 &,- 0111 &, 1445 & .0127 &,- 0675 &, 1435 &,- 1510 &, 1350 \\
\hline Karllık & & & & 1,0000 & 4430 &,- 7439 &, 3465 &, 7268 &,- 0839 & .4666 &, 2355 \\
\hline $\begin{array}{l}\text { Büyüme } \\
\text { fursatlar1 }\end{array}$ & & & & & 1,0000 &,- 4563 &, 0509 &, 4040 &,- 0613 &, 1731 & .0735 \\
\hline $\begin{array}{l}\text { Döviz } \\
\text { kuru } \\
\text { oran1 }\end{array}$ & & & & & & 1,0000 &,- 6754 &,- 8278 &, 0381 &,- 4979 &,- 3296 \\
\hline $\begin{array}{l}\text { Faiz } \\
\text { oranı }\end{array}$ & & & & & & & 1,0000 &, 4591 &,- 0211 &, 3747 &, 2448 \\
\hline $\begin{array}{l}\text { GSYIH } \\
\text { oranı }\end{array}$ & & & & & & & & 1,0000 &, 0321 &, 4407 &, 3781 \\
\hline $\begin{array}{l}\text { Kısa } \\
\text { vadeli } \\
\text { borç } \\
\text { oranı }\end{array}$ & & & & & & & & & 1,0000 &,- 7060 &, 8516 \\
\hline $\begin{array}{l}\text { Uzun } \\
\text { vadeli } \\
\text { borç } \\
\text { oranı }\end{array}$ & & & & & & & & & & 1,0000 &,- 2371 \\
\hline $\begin{array}{l}\text { Toplam } \\
\text { borç } \\
\text { oranı } \\
\end{array}$ & & & & & & & & & & & 1,0000 \\
\hline
\end{tabular}

\subsection{Kanonik Korelasyon Analizi Sonuçları}

Kanonik korelasyon katsayılarının anlamlılıklarını test etmek için "kanonik yük" kanonik çapraz yük" ve "gereksizlik indeksi" sonuçları yorumlanacaktır. Elde edilen ilk kanonik fonksiyon iki değişken seti arasındaki ilişkiyi maksimum yapacak biçimde elde edildiğinden, ayrıca her bir kanonik değişken çiftinin birbirinden bağımsız olması ve değişken setleri arasında bulunan farklı ilişkileri temsil etmesi nedeniyle ilk kanonik fonksiyonun yorumlanması yeterli görülmüştür. Çalışmada öncelikle küçük ölçekli işletmelere ilişkin yapılan analiz sonuçları sunulduktan sonra orta ölçekli işletmelere ilişkin yapılan analiz sonuçlarınayer verilecektir.

\subsubsection{Küçük Ölçekteki İşletmeler Açısından Kanonik Korelasyon Analizi Sonuçları}

Tablo 4. Küçük Ölçekli İşletmelerin Sermaye Yapısına Etki Eden İşletmeye Özgü Değişkenler İle Kaldıraç Oranlarına İlişkin Kanonik Korelasyon Katsayıları ve Test Sonuçları

\begin{tabular}{|c|c|c|c|c|c|c|}
\hline & $\begin{array}{c}\text { Kanonik } \\
\text { korelasyon } \\
\text { katsayıs1 (R) }\end{array}$ & $\begin{array}{c}\text { Kanonik } \\
\text { korelasyonun } \\
\text { karesi }\left(\mathbf{R}^{2}\right)\end{array}$ & $\begin{array}{l}\text { Wilk's } x \\
\text { değeri }\end{array}$ & Ki -Kare & $\begin{array}{c}\text { Serbestlik } \\
\text { derecesi }\end{array}$ & $\begin{array}{l}\text { Anlamlılık } \\
\text { seviyesi (p) }\end{array}$ \\
\hline 1 & 0,780 & 0,608 & 0,226 & 45,363 & 15,000 & 0,000 \\
\hline 2 & 0,575 & 0,330 & 0,578 & 16,717 & 8,000 & 0,033 \\
\hline 3 & 0,370 & 0,136 & 0,863 & 4,480 & 3,000 & 0,214 \\
\hline
\end{tabular}

Küçük ölçekli işletmelerin sermaye yapısına etki eden işletmeye özgü değişkenler ile kaldıraç oranlarına ilişkin kanonik korelasyon analizi sonuçlarına göre, birinci kanonik fonksiyon $(R=0,780)$ en anlamlı $(p=0,000)$ fonksiyon olarak tespit edilmiştir.

Tablo 4.1. Küçük Ölçekli İşletmelerin Sermaye Yapısına Etki Eden İşletmeye Özgü Faktörlere ve Kaldıraç Oranlarına Ait Kanonik Yükler ve Kanonik Çapraz Yükler

\begin{tabular}{|l|c|c|}
\hline \multirow{2}{*}{ Değişkenler } & Kanonik yük & Kanonik çapraz yük \\
\cline { 2 - 3 } & $\mathbf{X}_{\mathbf{1}}{ }^{*}$ & $\mathbf{Y}_{\mathbf{1}}{ }^{*}$ \\
\hline Likidite & 0,958 & 0,747 \\
\hline Büyüklük & $-0,833$ & $-0,650$ \\
\hline Varlık yapısı & $-0,208$ & $-0,162$ \\
\hline Karlılık & $-0,683$ & $-0,533$ \\
\hline Büyüme fırsatı & $-0,346$ & $-0,270$ \\
\hline & $\mathbf{Y}_{\mathbf{1}}{ }^{*}$ & $\mathbf{X}_{\mathbf{1}}{ }^{*}$ \\
\hline Kısa vadeli kaldıraç & $-0,239$ & $-0,186$ \\
\hline Uzun vadeli kaldıç & $-0,458$ & $-0,358$ \\
\hline Toplam kaldıraç & $-0,699$ & $-0,546$ \\
\hline
\end{tabular}


Tablo 4.1'de işletmeye özgü faktörler ile kaldıraç oranlarına ait kanonik yük ve kanonik çapraz yükler gösterilmiştir. Buna göre bağımsız değişken setine ait kanonik yük ve kanonik çapraz yükler incelendiğinde en fazla katkı sağlayan değişken likidite oranıdır. Bağımlı sete ait kanonik yükler ve kanonik çapraz yükler incelendiğinde ise kaldıraç oranları arasında en fazla katkı sağlayan değişken toplam kaldıraçoranıdır. İşaretler dikkate alındığında; kaldıraç oranlarıyla likidite oranının ters yönlü, diğer işletmeye özgü değişkenlerin ise aynı yönlü ilişkili olduğu saptanmıştır.

Tablo 4.2. Küçük Ölçekli İşletmelerin Sermaye Yapısına Etki Eden İşletmeye Özgü Faktörler ve Kaldıraç Oranları Setlerinin Açıklanan Varyansı ve Gereksizlik İndeksi

\begin{tabular}{|c|c|c|c|}
\hline \multirow{5}{*}{$\begin{array}{l}X{ }^{*} \text { değişken setinin kendi değişkenleriyle açılanan } \\
\text { varyansı }\end{array}$} & $\begin{array}{l}\text { Kanonik } \\
\text { değişken }\end{array}$ & Oran & Kümülatif oran \\
\hline & 1 & 0,448 & 0,448 \\
\hline & 2 & 0,193 & 0,641 \\
\hline & 3 & 0,132 & 0,773 \\
\hline & 1 & 0,273 & 0,273 \\
\hline \multirow{2}{*}{$\begin{array}{l}X{ }^{*} \text { değişken setinin zıt değişkenlerle açılanan } \\
\text { varyansı }\end{array}$} & 2 & 0,064 & 0,337 \\
\hline & 3 & 0,018 & 0,355 \\
\hline \multirow{3}{*}{$\begin{array}{l}Y^{*} \text { değişken setinin kendi değişkenleriyle açılanan } \\
\text { varyansı }\end{array}$} & 1 & 0.252 & 0.252 \\
\hline & $\frac{1}{2}$ & 0,20116 & 0,368 \\
\hline & 3 & 0,632 & 1,000 \\
\hline \multirow{3}{*}{$\begin{array}{l}Y^{*} \text { değişken setinin zıt değişkenlerle açılanan } \\
\text { varyansı }\end{array}$} & 1 & 0,153 & 0,153 \\
\hline & 2 & 0,038 & 0,191 \\
\hline & 3 & 0,086 & 0,277 \\
\hline
\end{tabular}

Tablo 4.2’ye göre kanonik değişkenler toplamda sermaye yapısı işletmeye özgü değişkenler kümesindeki değişimin \%77,3'ünü açıklamaktadır. Gereksizlik indeksine göre, sermaye yapısı değişkenlerindeki (bağımsız değişkenler) toplam değişimin \%35,5‘i kanonik kaldıraç oranı değişkenleri tarafından açıklanmaktadır. Kaldıraç oranları değişken setine (bağımlı değişken) bakıldığında buradaki kanonik değişkenlerin bağımlı sette açıkladığ oranı değişkenlerindeki toplam değişimin \%27,7'si sermaye yapısı bağımsız değişkenleri tarafından açıklanmaktadır.

Tablo 5. Kü̧̈ük Ölçekli İşletmelerin Sermaye Yapısına Etki Eden Makroekonomik Değişkenler İle Kaldıraç Oranlarına İlişkin Kanonik Korelasyon Katsayıları ve Test Sonuçları

\begin{tabular}{|c|c|c|c|c|c|c|}
\hline & $\begin{array}{c}\text { Kanonik } \\
\text { korelasyon } \\
\text { katsayıs1 (R) }\end{array}$ & $\begin{array}{c}\text { Kanonik } \\
\text { korelasyonun } \\
\text { karesi }\left(\mathbf{R}^{2}\right)\end{array}$ & $\begin{array}{c}\text { Wilk's } \lambda \\
\text { değeri }\end{array}$ & Ki -Kare & $\begin{array}{c}\text { Serbestlik } \\
\text { derecesi }\end{array}$ & $\begin{array}{l}\text { Anlamlılık } \\
\text { seviyesi (p) }\end{array}$ \\
\hline 1 & 0,718 & 0,515 & 0,454 & 24,866 & 9,000 & 0,003 \\
\hline 2 & 0,234 & 0,054 & 0,938 & 2,015 & 4,000 & 0,733 \\
\hline 3 & 0,088 & 0,007 & 0,992 & 0,245 & 1,000 & 0,620 \\
\hline
\end{tabular}

Küçük ölçekli işletmelerin sermaye yapısına etki eden makroekonomik değişkenler ile kaldıraç oranlarına ilişkin kanonik korelasyon analizi sonuçlarına göre, birinci kanonik fonksiyon $(R=0,718)$ en anlamlı $(p=0,003)$ fonksiyon olarak tespit edilmiştir. 
N. Yücedağ Erdinç - G. Sayılgan 12/1 (2020) 826-847

Tablo 5.1. Küçük Ölçekli İşletmelerin Sermaye Yapısına Etki Eden Makroekonomik Faktörler ve Kaldıraç Oranlarına Ait Kanonik Yükler ve Kanonik Çapraz Yükler

\begin{tabular}{|l|c|c|}
\hline \multirow{2}{*}{ Değişkenler } & Kanonik yük & Kanonik çapraz yük \\
\cline { 2 - 3 } & $\mathbf{X}_{\mathbf{1}}{ }^{*}$ & $\mathbf{Y}^{{ }^{*}}$ \\
\hline Döviz kuru & $-0,964$ & $-0,692$ \\
\hline Faiz oranı & 0,695 & 0,499 \\
\hline GSYİH büyüme oranı & 0,931 & 0,669 \\
\hline & $\mathbf{Y}_{\mathbf{1}}{ }^{*}$ & $\mathbf{X}^{{ }^{*}}$ \\
\hline Kisa vadeli kaldıraç & $-0,008$ & $-0,006$ \\
\hline Uzun vadeli kaldıraç & 0,696 & 0,500 \\
\hline Toplam kaldıraç & 0,517 & 0,372 \\
\hline
\end{tabular}

Tablo 5.1'e göre bağımsız değişken setine ait kanonik yük ve kanonik çapraz yükler incelendiğinde, en fazla katkı sağlayan değişken döviz kuru oranıdır. Bağımlı değişkenlere ait kanonik yük ve kanonik çapraz yüklere göre ise kaldıraç oranları arasında en fazla katkı sağlayan değişken uzun vadeli kaldıraçoranıdır. İşaretler dikkate alındığında; uzun vadeli kaldıraç ve toplam kaldıraç oranlarıyla döviz kuru oranının ters yönlü, faiz oranı ile GSYİH büyüme oranının ise aynı yönlü ilişkili olduğu saptanmıştır.

Tablo 5.2. Küçük Ölçekli İşletmelerin Sermaye Yapısına Etki Eden Makroekonomik Faktörler ve Kaldıraç Oranları Setlerinin Açılanan Varyansı ve Gereksizlik İndeksi

\begin{tabular}{|l|c|c|c|}
\hline \multirow{3}{*}{$\begin{array}{l}\text { X*değişken setinin kendi değişkenleriyle açıklanan } \\
\text { varyansı }\end{array}$} & $\begin{array}{c}\text { Kanonik } \\
\text { değişken }\end{array}$ & Oran & Kümülatif oran \\
\cline { 2 - 4 } & 1 & 0,760 & 0,760 \\
\cline { 2 - 4 } & 2 & 0,062 & 0,822 \\
\cline { 2 - 4 }$X^{*}$ değişken setinin zıt değişkenlerle açıklanan varyansı & 3 & 0,179 & 1,000 \\
\cline { 2 - 4 } & 1 & 0,392 & 0,392 \\
\cline { 2 - 4 } & 2 & 0,003 & 0,395 \\
\hline \multirow{3}{*}{$Y^{*}$ değişken setinin kendi değişkenleriyle açıklanan } & 3 & 0,001 & 0,396 \\
\cline { 2 - 4 } varyansı & & & \\
\cline { 2 - 4 } & 1 & 0,251 & 0,251 \\
\cline { 2 - 4 }$Y^{*}$ değişken setinin zıt değişkenlerle açıklanan varyansı & 2 & 0,105 & 0,356 \\
\cline { 2 - 4 } & 3 & 0,645 & 1,000 \\
\cline { 2 - 4 } & 1 & 0,129 & 0,129 \\
\cline { 2 - 4 } & 2 & 0,006 & 0,135 \\
\hline
\end{tabular}

Tablo 5.2'ye göre kanonik değişkenler toplamda sermaye yapısı makroekonomik değişkenler kümesindeki değişimin \%100'ünü açıklamaktadır. Gereksizlik indeksine göre, sermaye yapısı değişkenlerindeki (bağımsız değişkenler) toplam değişimin \%39,6'sı kanonik kaldıraç oranı değişkenleri tarafından açıklanmaktadır. Kaldıraç oranları değişken setine (bağımlı değişken) bakıldığında buradaki kanonik değişkenlerin bağımlı sette açıkladığı kısmın toplamını 1,000 olduğu görülmektedir. Gereksizlik indeksi incelendiğinde, kaldıraç oranı değişkenlerindeki toplam değişimin \%14’ü bağımsız değişkenler tarafından açıklanmaktadır. 
N. Yücedağ Erdinç - G. Sayılgan 12/1 (2020) 826-847

Tablo 6. Küçük Ölçekli İşletmelerin Sermaye Yapısına Etki Eden İşletmeye Özgü Değişkenler İle Makroekonomik Değişkenlere İlişkin Kanonik Korelasyon Katsayıları ve Test Sonuçları

\begin{tabular}{|c|c|c|c|c|c|c|}
\hline & $\begin{array}{l}\text { Kanonik } \\
\text { korelasyon } \\
\text { katsayısı (R) }\end{array}$ & $\begin{array}{l}\text { Kanonik } \\
\text { korelasyonun } \\
\text { karesi }\left(\mathbf{R}^{\mathbf{2}}\right)\end{array}$ & $\begin{array}{l}\text { Wilk's } \lambda \\
\text { değeri }\end{array}$ & Ki -Kare & $\begin{array}{l}\text { Serbestlik } \\
\text { derecesi }\end{array}$ & $\begin{array}{l}\text { Anlamlılık } \\
\text { seviyesi (p) }\end{array}$ \\
\hline 1 & 0,985 & 0,990 & 0,019 & 121,450 & 15,000 & 0,000 \\
\hline 2 & 0,593 & 0,361 & 0,639 & 13,679 & 8,000 & 0,091 \\
\hline 3 & 0,124 & 0,134 & 0,985 & 0,450 & 3,000 & 0,924 \\
\hline
\end{tabular}

Küçük ölçekli işletmelerin sermaye yapısına etki eden işletmeye özgü değişkenler ile makroekonomik değişkenlere ilişkin kanonik korelasyon analizi yapılmıştır. Buna göre, birinci kanonik fonksiyon $(R=0,985)$ en yüksek korelasyon katsayısına ve en yüksek anlamlılık seviyesine $(p=0,000)$ sahiptir. Diğer fonksiyonlar istatistiksel olarak anlamlı bulunmamıştır.

Tablo 6.1.Küçük Ölçekli İşletmelerin Sermaye Yapısına Etki Eden İşletmeye Özgü Faktörler ve Makroekonomik Faktörlere Ait Kanonik Yükler ve Kanonik Çapraz Yükler

\begin{tabular}{|l|c|c|}
\hline \multirow{2}{*}{ Değişkenler } & Kanonik yük & Kanonik çapraz yük \\
\cline { 2 - 3 } & $\mathbf{X}_{\mathbf{1}}{ }^{*}$ & $\mathbf{Y}_{\mathbf{1}}{ }^{*}$ \\
\hline Likidite & $-0,675$ & $-0,665$ \\
\hline Büyüklük & 0,990 & 0,976 \\
\hline Varlık yapısı & $-0,071$ & $-0,070$ \\
\hline Karlılık & 0,745 & 0,734 \\
\hline Büyüme firsatı & 0,399 & 0,394 \\
\hline & $\mathbf{Y}_{\mathbf{1}}{ }^{*}$ & $\mathbf{X}_{\mathbf{1}}{ }^{*}$ \\
\hline Döviz kuru & $-0,887$ & $-0,874$ \\
\hline Faiz oranı & 0,585 & 0,576 \\
\hline GSYïH büyüme oranı & 0,988 & 0,974 \\
\hline
\end{tabular}

İşletmeye özgü değişken setine ait kanonik yük ve kanonikçapraz yükler incelendiğinde, en fazla katkı sağlayan değişken işletme büyüklüğü olarak tespit edilmiştir. Makroekonomik faktörlere göre kanonik yük ve kanonik çapraz yüklere göre ise en fazla katkı sağlayan değişken GSYİH büyüme oranı olarak saptanmıştır. İşaretler dikkate alındığında, döviz kuru oranı ile likidite ve varlık yapısı değişkeni aynı yönlü, büyüklük, karlılık ve büyüme fırsatı değişkenlerinin ise ters yönlü ilişkili olduğu tespit edilmiştir.

Tablo 6.2.Küçük Ölçekli İşletmelerin Sermaye Yapısına Etki Eden İşletmeye Özgü Faktörler ve Makroekonomik Faktörler Setlerinin Açıklanan Varyansı ve Gereksizlik İndeksi

\begin{tabular}{|c|c|c|c|}
\hline \multirow{3}{*}{$\begin{array}{l}X * \text { değişken setinin kendi değiş̧kenleriyle açılanan } \\
\text { varyansı }\end{array}$} & $\begin{array}{l}\text { Kanonik } \\
\text { değişken }\end{array}$ & Oran & Kümülatif oran \\
\hline & 1 & 0,431 & 0,431 \\
\hline & 2 & 0,178 & 0,609 \\
\hline \multirow{4}{*}{$\begin{array}{l}X * \text { değişken setinin zıt değişkenlerle açılanan } \\
\text { varyansı }\end{array}$} & 3 & 0,091 & 0,692 \\
\hline & 1 & 0,418 & 0,418 \\
\hline & 2 & 0,062 & 0,480 \\
\hline & 3 & 0,001 & 0,481 \\
\hline \multirow{3}{*}{$\begin{array}{l}Y^{*} \text { değişken setinin kendi değişkenleriyle açılanan } \\
\text { varyansı }\end{array}$} & 1 & 0,701 & 0,701 \\
\hline & 2 & 0,075 & 0,776 \\
\hline & 3 & 0,224 & 1,000 \\
\hline \multirow{3}{*}{$\begin{array}{l}Y^{*} \text { değişken setinin zıt değişkenlerle açılanan } \\
\text { varyansı }\end{array}$} & 1 & 0,681 & 0,681 \\
\hline & 2 & 0,026 & 0,707 \\
\hline & 3 & 0,003 & 0,710 \\
\hline
\end{tabular}


Tablo 6.2'ye görekanonik değişkenler toplamda sermaye yapısı makroekonomik değişkenleri kümesindeki değişimin \%69,2'sini açıklamaktadır. Gereksizlik indeksine göre, sermaye yapısı işletmeye özgü değişkenlerindeki toplam değişimin \% 48,1 'i sermaye yapısına etki eden kanonik makroekonomik faktörler setindeki değişkenler tarafından açıklanmaktadır. Makroekonomik faktörlere ilişkin açıklanan varyans oranına göre, kanonik değişkenler toplamda makroekonomik değişken kümesindeki değişimin \%100'ünü açıklamaktadır. Gereksiz indeksine göre sermaye yapısına etki eden makroekonomik değişkenlerindeki toplam değişimin \%71'i, sermaye yapısı kanonik işletmeye özgü değişkenleri tarafından açıklanmaktadır.

\subsubsection{Orta Ölçekteki İşletmeler Açısından Kanonik Korelasyon Analizi Sonuçları}

Tablo 7. Orta Ölçekli İşletmelerin KanonikKorealsyon Katsayıları ve Test Sonuçları

\begin{tabular}{|c|c|c|c|c|c|c|}
\hline & $\begin{array}{c}\text { Kanonik } \\
\text { korelasyon } \\
\text { katsayıs1 (R) }\end{array}$ & $\begin{array}{c}\text { Kanonik } \\
\text { korelasyonun } \\
\text { karesi }\left(\mathbf{R}^{2}\right)\end{array}$ & $\begin{array}{l}\text { Wilk's } \lambda \\
\text { değeri }\end{array}$ & Ki -Kare & $\begin{array}{c}\text { Serbestlik } \\
\text { derecesi }\end{array}$ & $\begin{array}{l}\text { Anlamlılık } \\
\text { seviyesi (p) }\end{array}$ \\
\hline 1 & 0,965 & 0,931 & 0,031 & 105,509 & 15,000 & 0,000 \\
\hline 2 & 0,645 & 0,416 & 0,454 & 24,088 & 8,000 & 0,002 \\
\hline 3 & 0,471 & 0,221 & 0,778 & 7,564 & 3,000 & 0,054 \\
\hline
\end{tabular}

Tablo 7'de orta ölçekli işletmelerin sermaye yapısına etki eden işletmeye özgü faktörler ile kaldıraç oranlarına ilişkin yapılan kanonik korelasyon katsayıları yer almaktadır. Buna göre, birinci kanonik korelasyon en yüksek korelasyon $\left(R_{1}=0,965\right)$ katsayısına sahiptir ve en anlamlı $(p=0,000)$ sonucu vermektedir.

Tablo 7.1. Orta Ölçekli İşletmelerin Sermaye Yapısına Etki Eden İşletmeye Özgü Faktörlere ve Kaldıraç Oranlarına Ait Kanonik Yükler ve Kanonik Çapraz Yükler

\begin{tabular}{|l|c|c|}
\hline \multirow{2}{*}{ Değişkenler } & Kanonik yük & Kanonik çapraz yük \\
\cline { 2 - 3 } & $\mathbf{X}_{\mathbf{1}}{ }^{*}$ & $\mathbf{Y}_{\mathbf{1}}{ }^{*}$ \\
\hline Likidite & 0,971 & 0,937 \\
\hline Büyüklük & $-0,950$ & $-0,917$ \\
\hline Varlık yapısı & $-0,184$ & $-0,177$ \\
\hline Karlılı & $-0,528$ & $-0,510$ \\
\hline Büyüme firsatı & $-0,369$ & $-0,356$ \\
\hline & $\mathbf{Y}_{\mathbf{1}}{ }^{*}$ & $\mathbf{X}_{\mathbf{1}}{ }^{*}$ \\
\hline Kisa vadeli kaldıraç & $-0,950$ & $-0,916$ \\
\hline Uzun vadeli kaldıraç & $-0,845$ & $-0,816$ \\
\hline Toplam kaldıraç & $-0,999$ & $-0,963$ \\
\hline
\end{tabular}

Anlamlı olan birinci kanonik fonksiyona ait kanonik yükler incelendiğinde (Tablo 7.1),kanonik bağımsız değişkene $\left(\mathrm{X}_{1}^{*}\right)$ en büyük katkıyı yapan orijinal değişken likidite değişkenidir. $\mathrm{Y}_{1}^{*}$ kanonik kaldıraç değişkeni (kanonik bağımlı değişken) ile bağımsız değişkenlerin kanonik çapraz yükleri incelendiğinde; kanonik yüklerde olduğu gibi en büyük katkı likidite değişkenine aittir. Borç oranları için hem kanonik yükler hem de kanonik çapraz yükler açısından toplam kaldıraç oranı en önemli değişken olarak tespit edilmiştir. İşaretler dikkate alındığında; kaldıraç oranları (kısa, uzun ve toplam) sırasıyla büyüklük, karlılık, büyüme fırsatları ve varlık yapısı değişkenleri ile aynı yönde, likidite değişkeni ile ters yönlü ilişkili olduğu tespit edilmiştir.

Tablo 7.2. Orta Ölçekli İşletmelerin Sermaye Yapısına Etki Eden İşletmeye Özgü Faktörler ve Kaldıraç Oranları Setlerinin Açıklanan Varyansı ve Gereksizlik İndeksi

\begin{tabular}{|c|c|c|c|}
\hline & $\begin{array}{c}\text { Kanonik } \\
\text { değişken }\end{array}$ & Oran & Kümülatif oran \\
\cline { 2 - 4 } & 1 & 0,459 & 0,459 \\
\hline
\end{tabular}




\begin{tabular}{|c|c|c|c|}
\hline \multirow{4}{*}{$\begin{array}{l}X * \text { değişken setinin kendi değişkenleriyle açıklanan } \\
\text { varyansı }\end{array}$} & 2 & 0,120 & 0,579 \\
\hline & 3 & 0,096 & 0,675 \\
\hline & 1 & 0,427 & 0,427 \\
\hline & 2 & 0,050 & 0,477 \\
\hline$X^{*}$ değişken setinin zıt değişkenlerle açıklanan varyansı & 3 & 0,021 & 0,498 \\
\hline \multirow{4}{*}{$\begin{array}{l}Y^{*} \text { değişken setinin kendi değişkenleriyle açılanan } \\
\text { varyansı }\end{array}$} & 1 & 0,871 & 0,871 \\
\hline & 2 & 0,117 & 0,988 \\
\hline & 3 & 0,011 & 0,999 \\
\hline & 1 & 0,811 & 0,811 \\
\hline \multirow[t]{2}{*}{$\mathrm{Y}^{*}$ değişken setinin zıt değişkenlerle açıklanan varyansı } & 2 & 0,049 & 0,860 \\
\hline & 3 & 0,003 & 0,863 \\
\hline
\end{tabular}

Açıklanan varyans oranına göre, kanonik değişkenler toplamda sermaye yapısı işletmeye özgü değişkenleri kümesindeki değişimin \%67,5'ini açıklamaktadır. Gereksizlik indeksine göre ise, sermaye yapısı işletmeye özgü değişkenlerindeki (bağımsız değişkenler) toplam değişimin \%49,8‘i kanonik kaldıraç oranı değişkenleri tarafından açıklanmaktadır.

Kaldıraç oranları değişken setine (bağımlı değişken) bakıldığında buradaki kanonik değişkenlerin bağımlı sette açıkladığı kısmın toplamını 0,999 olduğu görülmektedir. Gereksizlik indeksi incelendiğinde, kaldıraç oranı değişkenlerindeki toplam değişimin \%86,3'ü sermaye yapısı kanonik işletmeye özgü değişkenleri (bağımsız değişkenler) tarafından açıklanmaktadır.

Tablo 8. Orta Ölçekli İşletmelerin Sermaye Yapısına Etki Eden Makroekonomik Değişkenler İle Kaldıraç Oranlarına İlişkin Kanonik Korelasyon Katsayıları ve Test Sonuçları

\begin{tabular}{|c|c|c|c|c|c|c|}
\hline & $\begin{array}{c}\text { Kanonik } \\
\text { korelasyon } \\
\text { katsayıs (R) }\end{array}$ & $\begin{array}{c}\text { Kanonik } \\
\text { korelasyonun } \\
\text { karesi }\left(\mathbf{R}^{2}\right)\end{array}$ & $\begin{array}{l}\text { Wilk's } x \\
\text { değeri }\end{array}$ & Ki -Kare & $\begin{array}{c}\text { Serbestlik } \\
\text { derecesi }\end{array}$ & $\begin{array}{l}\text { Anlamlılık } \\
\text { seviyesi (p) }\end{array}$ \\
\hline 1 & 0,932 & 0,868 & 0,103 & 71,689 & 9,000 & 0,000 \\
\hline 2 & 0,464 & 0,215 & 0,778 & 7,889 & 4,000 & 0,096 \\
\hline 3 & 0,092 & 0,008 & 0,991 & 0,269 & 1,000 & 0,604 \\
\hline
\end{tabular}

Orta ölçekli işletmelerin sermaye yapısına etki eden makroekonomik faktörler ve kaldıraç oranlarına ilişkin analiz sonuçlarında ise sadece birinci kanonik fonksiyon $(R=0,932)$ anlamlı bulunmuştur $(p=0,000)$.

Tablo 8.1. Orta Ölçekli İşletmelerin Sermaye Yapısına Etki Eden Makroekonomik Faktörler ve Kaldıraç Oranlarına Ait Kanonik Yükler ve Kanonik Çapraz Yükler

\begin{tabular}{|l|c|c|}
\hline \multirow{2}{*}{ Değişkenler } & Kanonik yük & Kanonik çapraz yük \\
\cline { 2 - 3 } & $\mathbf{X}_{\mathbf{1}}{ }^{*}$ & $\mathbf{Y}_{\mathbf{1}}{ }^{*}$ \\
\hline Döviz kuru & $-0,965$ & $-0,899$ \\
\hline Faiz oranı & 0,732 & 0,682 \\
\hline GSYİH büyüme oranı & 0,915 & 0,852 \\
\hline & $\mathbf{Y}_{\mathbf{1}}{ }^{*}$ & $\mathbf{X}^{*}$ \\
\hline Kısa vadeli kaldıraç & 0,888 & 0,828 \\
\hline Uzun vadeli kaldıraç & 0,906 & 0,844 \\
\hline Toplam kaldıraç & 0,993 & 0,925 \\
\hline
\end{tabular}

Bağımsız değişken setine ait kanonik yük ve kanonik çapraz yükler incelendiğinde (Tablo 8.1) en fazla katkı sağlayan değişken döviz kuru oranı olarak saptanmıştır. Bağımlı değişkenlere ait kanonik yük ve kanonik çapraz yüklere göre ise kaldıraç oranları arasında en fazla katkı sağlayan değişken toplam kaldıraçoranı olarak tespit edilmiştir. İ̧saretler dikkate alındığında; kaldıraç oranlarıyla döviz kuru oranının ters yönlü, faiz oranı ile GSYİH büyüme oranının ise aynı yönlü olduğu saptanmıştır. 
Tablo 8.2. Orta Ölçekli İşletmelerin Sermaye Yapısına Etki Eden Makroekonomik Faktörler ve Kaldıraç Oranları Setlerinin Açıklanan Varyansı ve Gereksizlik İndeksi

\begin{tabular}{|c|c|c|c|}
\hline \multirow{4}{*}{$\begin{array}{l}X^{*} \text { değişken setinin kendi değişkenleriyle açılanan } \\
\text { varyansı }\end{array}$} & $\begin{array}{l}\text { Kanonik } \\
\text { değişken }\end{array}$ & Oran & Kümülatif oran \\
\hline & 1 & 0,767 & 0,767 \\
\hline & 2 & 0,178 & 0,945 \\
\hline & 3 & 0,054 & 0,999 \\
\hline \multirow{3}{*}{$\begin{array}{l}X * \text { değişken setinin zıt değişkenlerle açılanan } \\
\text { varyansı }\end{array}$} & 1 & 0,666 & 0,666 \\
\hline & 2 & 0,038 & 0,704 \\
\hline & 3 & 0,000 & 0,704 \\
\hline & 1 & 0,865 & 0,865 \\
\hline $\mathrm{Y}^{*}$ değişken setinin kendi değişkenleriyle açıklanan & 2 & 0,041 & 0,906 \\
\hline varyans1 & 3 & 0,094 & 1,000 \\
\hline & 1 & 0,751 & 0,751 \\
\hline \multirow[b]{2}{*}{$\begin{array}{l}Y^{*} \text { değişken setinin zıt değişkenlerle açılanan } \\
\text { varyansı }\end{array}$} & 2 & 0,009 & 0,760 \\
\hline & 3 & 0,001 & 0,761 \\
\hline
\end{tabular}

Tablo 8.2'e göre kanonik değişkenler toplamda sermaye yapısı makroekonomik değişkenleri kümesindeki değişimin \%99,9'unu açıklamaktadır. Gereksizlik indeksine göre, sermaye yapısı makroekonomik değişkenlerindeki (bağımsız değişkenler) toplam değişimin \%70,4’ü kanonik kaldıraç oranı değişkenleri tarafından açıklanmaktadır. Kaldıraç oranları değişken setine (bağımlı değişken) bakıldığında buradaki kanonik değişkenlerin bağımlı sette açıkladığı kısmın toplamını 1,000 olduğu görülmektedir. Gereksizlik indeksi incelendiğinde, kaldıraç oranı değişkenlerindeki toplam değişimin \%76,1'i sermaye yapısı kanonik makroekonomik değişkenleri (bağımsız değişkenler) tarafından açılanmaktadır.

Tablo 9. Orta Ölçekli İşletmelerin Sermaye Yapısına Etki Eden İşletmeye Özgü Değişkenler İle Makroekonomik Değişkenlere İlişkin Kanonik Korelasyon Katsayıları ve Test Sonuçları

\begin{tabular}{|c|c|c|c|c|c|c|}
\hline & $\begin{array}{c}\text { Kanonik } \\
\text { korelasyon } \\
\text { katsayısı (R) }\end{array}$ & $\begin{array}{c}\text { Kanonik } \\
\text { korelasyonun } \\
\text { karesi }\left(\mathbf{R}^{2}\right)\end{array}$ & $\begin{array}{c}\text { Wilk's } \lambda \\
\text { değeri }\end{array}$ & Ki -Kare & $\begin{array}{c}\text { Serbestlik } \\
\text { derecesi }\end{array}$ & $\begin{array}{l}\text { Anlamlılık } \\
\text { seviyesi (p) }\end{array}$ \\
\hline 1 & 0,995 & 0,990 & 0,006 & 157,321 & 15,000 & 0,000 \\
\hline 2 & 0,601 & 0,361 & 0,552 & 18,101 & 8,000 & 0,020 \\
\hline 3 & 0,367 & 0,134 & 0,865 & 4,418 & 3,000 & 0,220 \\
\hline
\end{tabular}

Orta ölçekli işletmelerin sermaye yapısına etki eden işletmeye özgü ve makroekonomik değişkenlere ilişkin kanonik korelasyon katsayılarına göre birinci kanonik fonksiyon $(R=0,995)$ en anlamlı sonucu $(p=0,000)$ vermiş, bu korelasyonun karesi $\left(R^{2}=0,990\right)$ ise işletmeye özgü faktörlerin, tüm makroekonomik değişkenlerin \%99'unu açıkladığını göstermektedir.

Tablo 9.1.Orta Ölçekli İşletmelerin Sermaye Yapısına Etki Eden İşletmeye Özgü Faktörler ve Makroekonomik Faktörlere Ait Kanonik Yükler ve Kanonik Çapraz Yükler

\begin{tabular}{|l|c|c|}
\hline \multirow{2}{*}{ Değişkenler } & Kanonik yük & Kanonik çapraz yük \\
\cline { 2 - 3 } & $\mathrm{X}{ }^{*}$ & $\mathrm{Y}_{1}{ }^{*}$ \\
\hline
\end{tabular}


N. Yücedağ Erdinç - G. Sayılgan 12/1 (2020) 826-847

\begin{tabular}{|l|c|c|}
\hline Likidite & $-0,803$ & $-0,798$ \\
\hline Büyüklük & 0,987 & 0,982 \\
\hline Varlık yapısı & 0,115 & 0,114 \\
\hline Karlılık & 0,730 & 0,726 \\
\hline Büyüme firsatı & 0,250 & 0,248 \\
\hline & $\mathbf{Y}_{\mathbf{1}}{ }^{*}$ & $\mathbf{X}_{\mathbf{1}}{ }^{*}$ \\
\hline Döviz kuru & $-0,858$ & $-0,854$ \\
\hline Faiz oranı & 0,497 & 0,494 \\
\hline GSYİH büyüme oranı & 0,998 & 0,993 \\
\hline
\end{tabular}

İşletmeye özgü değişken setine ait kanonik yük ve kanonik çapraz yükler incelendiğinde (Tablo 9.1) en fazla katkı sağlayan değişken işletme büyüklüğüdür. Makroekonomik değişkenler setinde hem kanonik yük hem de kanonik çapraz yüklere göre ise en fazla katkı sağlayan değişken GSYİH büyüme oranıdır. İşaretler dikkate alındığında, döviz kuru oranı ile likidite değişkeni aynı yönlü, diğer işletmeye özgü değişkenlerin ise döviz kuru oranı ile ters yönlü ilişkili olduğu tespit edilmiştir.

Tablo 9.2. Orta Ölçekli İşletmelerin Sermaye Yapısına Etki Eden İşletmeye Özgü Faktörler ve Makroekonomik Faktörler Setlerinin Açıklanan Varyansı ve Gereksizlik İndeksi

\begin{tabular}{|c|c|c|c|}
\hline \multirow{3}{*}{$\begin{array}{l}X^{*} \text { değişken setinin kendi değişkenleriyle açıklanan } \\
\text { varyansı }\end{array}$} & $\begin{array}{l}\text { Kanonik } \\
\text { değişken }\end{array}$ & Oran & Kümülatif oran \\
\hline & 1 & 0,445 & 0,445 \\
\hline & 2 & 0,109 & 0,554 \\
\hline \multirow{4}{*}{$\begin{array}{l}X^{*} \text { değişken setinin zıt değişkenlerle açılanan } \\
\text { varyansı }\end{array}$} & 3 & 0,173 & 0,727 \\
\hline & 1 & 0,441 & 0,441 \\
\hline & 2 & 0,040 & 0,481 \\
\hline & 3 & 0,023 & 0,504 \\
\hline \multirow{3}{*}{$\begin{array}{l}Y^{*} \text { değişken setinin kendi değişkenleriyle açıklanan } \\
\text { varyansı }\end{array}$} & 1 & 0,660 & 0,660 \\
\hline & 2 & 0,215 & 0,875 \\
\hline & 3 & 0,125 & 1,000 \\
\hline \multirow{3}{*}{$\begin{array}{l}Y^{*} \text { değişken setinin zıt değişkenlerle açıklanan } \\
\text { varyansı }\end{array}$} & 1 & 0,653 & 0,653 \\
\hline & 2 & 0,078 & 0,731 \\
\hline & 3 & 0,017 & 0,748 \\
\hline
\end{tabular}

Tablo 9.2'ye göre kanonik değişkenler toplamda sermaye yapısı makroekonomik değişkenler kümesindeki değişimin \%72,7'sini açıklamaktadır. Gereksizlik indeksine göre, sermaye yapısı işletmeye özgü değişkenlerindeki toplam değişimin \%50,4 ü sermaye yapısına etki eden kanonik makroekonomik faktörler setindeki değişkenler tarafından açıklanmaktadır. Makroekonomik faktörlere ilişkin açıklanan varyans oranı ve gereksizlik indeksine göre ise, kanonik değişkenler toplamda makroekonomik değişken kümesindeki değişimin \%100'ünü açıklamaktadır. Gereksiz indeksine göre sermaye yapısına etki eden makroekonomik değişkenlerindeki toplam değişimin \%74,8'i kanonik işletmeye özgü değişkenler tarafından açıklanmaktadır.

\section{SONUÇ VE ÖNERİLER}

Bu çalışma Borsa İstanbul'da faaliyette bulunan imalat sektörü işletmelerinin sermaye yapısına etki eden işletmeye özgü ve makroekonomik değişkenlerin işletmelerin sermaye yapısı kararlarında hangi faktörlerin katkısının ne kadar olduğu hem ayrı ayrı hem de içsel ve dışsal değişkenler birlikte analiz edilerek incelemeyi amaçlamıştır. Bu kapsamda 2009-2017 yılları arasında 134 işletme aktif büyüklüklerine göre büyük, orta ve küçük ölçekli işletmeler olarak gruplandırılarak aralarındaki benzerlik ve farklılıklar araştırılmıştır. Gruplandırma neticesinde küçük ve orta ölçekli işletme niteliğinde yer alan 110 işletme kanonik korelasyon analizi ile incelenmiştir.

İşletmeye özgü değişkenler ile kaldıraç oranlarına ilişkin yapılan analizlerde kaldıraç oranları arasında en önemli değişkenin toplam kaldıraç oranı olduğu tespit edilmiştir. Kaldıraç oranları içerisinde orta ölçekli 


\section{N. Yücedağ Erdinç - G. Sayılgan 12/1 (2020) 826-847}

işletmelerin kısa vadeli borç kullanımını, uzun vadeli borç kullanımına tercih etmesi küçük ölçekli işletmelerden farklı bir sonuç olarak saptanmıştır. Orta ölçekli işletmeler ihtiyacı olan borcu kısa vadede temin edebilmişse uzun vadeli borç kullanmayacaktır. Kısa vadeli borçlarını ödeyebilme gücünü gösteren likidite oranının da bu işletmeler için en fazla katkı sağlayan değişken olarak bulunması bu sonucu desteklemektedir. İşletmeye özgü değişkenler içerisinde hem orta ölçekli hem de küçük ölçekli işletmeler açısından likidite oranı en önemli değişken olarak tespit edilmiştir. Likidite oranı ile borçluluk arasındaki negatif ilişki; işletmenin likit varlıklarının gücü ne kadar yüksekse, borçlanma gereksinimlerinin o kadar az olacağının bir göstergesi olarak ifade edilebilir. İşletmeler faaliyetlerini ve yatırımlarını kendi kaynaklarından finanse etmek eğiliminde olabilirler. Ayrıca düşük likidite oranı borç maliyetini düşürerek daha fazla borç kullanılmasını teşvik etmektedir (Zhu, 2014: 150). Elde edilen bulgular finansman hiyerarşisi teorisini desteklemektedir. Ayrıca likidite ve kaldıraç arasındaki ters yönlü ilişki borç verenlerle hissedarlar arasında bilgi asimetrisinden de kaynaklanabilir. Küçük ve orta ölçekli işletmelerde bilgi asimetrisi problemi büyük ölçekli işletmelere nazaran daha fazladır (Gonzales ve Gonzales, 2011: 4746). İşletme büyüklüğü değişkeni küçük ölçekli ve orta ölçekli işletmeler için ikinci önemli değişken olarak tespit edilmiş, kaldıraç ile arasında pozitif ilişki saptanmıştır. Bulunan bu sonuç ödünleşme teorisini destekler niteliktedir. Büyük işletmelerin iflas olasılıkları daha az olduğundan piyasada kredibiliteleri daha yüksek olmaktadır (Buvanendra vd. 2016: 589). Büyük işletmeler kurumsal yapılarını tamamlamış işletmeler olduklarından borcun temsil maliyeti daha azdır ve bu işletmeler varlıklarını çeşitlendirebildiğinden risklerini azaltabilmektedir. Bilgi asimetrisi ve yüksek enflasyonun olduğu gelişmekte olan ülkelerde, küçük ölçekli işletmeler çoğunlukla daha yüksek faiz oranı maliyetiyle karşı karşıya kalmaktadır. Aynı zamanda orta ve küçük ölçekli işletmeler daha riskli olmaları ve temerrüt olasılıklarının daha fazla olması gibi nedenlerle büyük işletmelere göre daha az dış kaynaklardan yararlanabilmektedir (Gonzales ve Gonzales, 2011: 4746).Küçük işletmeler iç kaynak kullanmayı bu nedenlerle tercih etmektedir (Bas vd., 2010: 25). Karlılık ile kaldıraç arasında literatürde genel kabul görmüş ters yönlü ilişkinin aksine çalışmada ödünleşme teorisini destekler şekilde aynı yönlü ilişki saptanmıştır. Karlı işletmeler daha düşük iflas riskine sahip olduklarından daha kolay şartlarda ve daha fazla miktarda borç kullanabilmektedir (Gülşen ve Ülkütaş, 2012: 51). Aynı zamanda işletmelerin karlılığı arttıkça vergilendirilecek geliri de artmaktadır. Dolayısıyla, borçlanmanın vergi kalkanı etkisinden daha çok faydalanmak isteyen işletmeler daha yüksek düzeyde borç kullanımını tercih edebilir (Dinçergök, 2017: 94). Büyüme fırsatları ve varlık yapısı değişkenleriyle kaldıraç oranları arasında tüm analiz bulgularına göre güçlü olmayan bir ilişki tespit edilmiştir. Orta ve küçük ölçekli işletmelerde kaldıraç oranlarıyla varlık yapısı değişkeni arasında aynı yönde ilişki, bu işletmelerin varlık yapılarında, duran varlıklara daha fazla ağırlık verdiği ve bu sayede daha uzun vadelerde ve daha kolay imkanlarda borç kullanabildiği şeklinde açılanabilir (Titman ve Wessels,1988; Harris ve Raviv, 1991).

Makroekonomik değişkenler ile kaldıraç oranlarına ilişkin sonuçlara göre, küçük ölçekli işletmelerde uzun vadeli kaldıraç oranı en önemli değişken olurken orta ölçekli işletmelerde ise en önemli kaldıraç değişkeni toplam kaldıraç oranı olarak tespit edilmiştir. Bir diğer farklı sonuç, küçük ölçekli işletmelerde, orta ölçekli işletmelerden farklı olarak, kısa vadeli kaldıraç oranının oldukça düşük negatif katsayı almış olmasıdır. Bu sonuç küçük ölçekli işletmelerin uzun vadeli borç kullanımını kısa vadeli borçlanmaya tercih ettikleri şeklinde yorumlanabilir. Bu işletmeler ekonomik genişleme dönemlerinde yatırım yapmak istediklerinden dış kaynakla finansmandan yararlanmak isteyebilirler. 2009-2017 dönemi içerisinde reel sektörün borçlanma oranlarına bakıldığında çoğunlukla uzun vadeli ve ağırlıklı olarak yabancı para cinsinden borçlandıkları görülmektedir (www.tcmb.gov.tr). Makroekonomik değişkenler içerisinde döviz kuru ile kaldıraç arasındaki ters yönlü ilişki küçük ve orta ölçekli işletmelerde en fazla katkı yapan makroekonomik değişken olarak tespit edilmiştir. Bu sonuç, finansal yapı açısından büyük işletmelere göre KOBİlerin daha güçsüz olmaları kısa vadedeki dalgalanmalardan daha kolay etkilenmelerine; ihracat hacmi bakımından ise daha az rekabetçi olmaları kur uyumsuzluklarına bilançoda daha fazla rastlanmasına neden olabileceği şeklinde açıklanabilir. Banka odaklı bir ülke olan Türkiye'de işletmelerin yabancı para cinsinden aldıkları kredileri ödeyememesi, bankacılık sektörünün de bu krizlerden etkilenmesine hatta ülkede ciddi bir kriz ortamının oluşmasına sebep olabilmektedir. Sonuç olarak Türkiye'de reel kurlar arttıkça, sermaye girişi olması nedeniyle faizler düşmektedir. Bu nedenle işletmeler sıcak para girişinin yüksek olduğu dönemlerde daha fazla kaldıraç kullanma eğiliminde olmuşlardır. Aynı zamanda GSYİH büyüme oranı arttıkça, büyümeyi finanse etmek için işletmelerin sermaye ihtiyaçları artmakta buna paralel olarak kaldıraç kullanım oranının da artması tespit edilen sonuçlarla uyumludur. 
Çalışmada son olarak işletmeye özgü değişkenler ile makroekonomik değişkenler arasındaki ilişkiler incelenmiştir. Tüm analiz sonuçlarında GSYİH büyüme oranı ile işletme büyüklüğü arasında aynı yönlü ilişki bulunmuştur. Küresel olarak likidite ve büyüklük kaldıraç kullanımında önemli faktör olarak ortaya çıkmış, büyüklük ve karlılığın eşlik ettiği durumlarda sermaye yapısında likiditenin katkısı negatif olarak tespit edilmiştir. Orta ölçekli işletmelerde ise likidite oranı ikinci önemli değişken olarak tespit edilmiştir. Küçük ölçekli işletmelerde ise işletme büyüklüğünden sonra en fazla katkı yapan değişken karlılık oranı olarak saptanmıştır. Büyüklük ve karlılık değişkenlerinin pozitif ve yüksek olması, küçük ölçekli işletmeler için likidite sorunu yaşanmayacağının bir göstergesi olabilir. Diğer bir farklı sonuç ise varlık yapısı değişkeninin en az katkı sağlayan değişken olarak tespit edilmesi ve küçük ölçekli işletmelerde negatif katsayı alırken orta ölçekli işletmelerde ise pozitif katsayı almış olmasıdır. Ülkedeki ekonomik iyimserlik iflas maliyetlerinin azalması, yatırım olanaklarının artması buna bağlı olarak üretimin artış göstermesiyle işletmeler için borç kullanma potansiyellerinde artışa neden olabilir. Bu durumda, küçük ölçekli işletmelerin çok sayıda maddi varlığa sahip olmak yerine yatırım yapmayı tercih ettikleri söylenebilir. Özetle, yapılan analiz sonucunda Borsa İstanbul'da kayıtlı olan küçük ve orta ölçekli imalat sektörü işletmelerinin,2009-2017 yılları arasında hem finansman hiyerarşisi teorisine hem de dengeleme teorisine uygun hareket ettikleri söylenebilir. Çalışmada literatürde yapılan çalışmalardan farklı olarak işletmeye özgü ve makroekonomik değişkenlerin kendi aralarındaki ilişkileri incelenmiş ve en fazla katkı yapan işletmeye özgü ve makroekonomik değişkenler eşzamanlı olarak analiz edilmiştir. Çalışmanın daha uzun yılları kapsayacak şekilde ya da farklı değişkenlerin analiz edilmesi ile ileride bir çalışma yapılabilir.

\section{Kaynakça}

Acaravcı, S. ve Doğukanlı, H. (2004). Türkiye'de Sermaye Yapısını Etkileyen Faktörlerin İmalat Sanayinde Sınanması, İktisat İşletme ve Finans Dergisi, 19, (225), 43-57.

Akgüç, Ö. (1998). Finansal Yönetim, İstanbul, Avcı ol Basım-Yayın.

Akhtar, P., Husnain, M. andMukhtar, M. A. (2010). TheDeterminants Of CapitalStructure: A Case From Pakistan TextileSector (SpinningUnits), Proceedings of $2^{\text {nd }}$ InternationalConference on Business Management.

Akman, E. (2012). Sermaye Yapısını Belirleyen İşletmeye Özgü Faktörler: İMKB’de İşlem Gören Sanayi Firmaları Üzerine Bir Panel Veri Uygulaması. (Yayımlanmamış Doktora Tezi). Bülent Ecevit Üniversitesi Sosyal Bilimler Enstitüsü, İşletme Ana Bilim Dalı, Zonguldak.

Ata, H.A. ve A ̆̆, Y. (2010). Firma Karakteristiğinin Sermaye Yapısı Üzerindeki Analizinin Etkisi, Ekonometri ve İstatistik, (11), 45-60.

Bauer, P. (2004). Capital Structure Of Listed Companies in Visegrad Countries, Prague Economic Papers, 2, 159175.

Bas, T., Muradoglu, G. and Phylaktis, K. (2009). Determinants Of Capital Structure in Developing Countries,WorkingPaper, Cass Business School.

Bolat, B.A. (2004).İmalat Sanayinde Verimliliği Ve Karlılığı Etkileyen Faktörlerin Araştırılması.(Yayımlanmamış Yüksek Lisan Tezi). İstanbul Üniversitesi Sosyal Bilimler Enstitüsü, İşletme ABD, Sayısal Yöntemler Bilim Dalı, İstanbul.

Booth, L., Aivazian, V., Demirguc-Kunt A. and Maksimovic, V. (2001). Capital Structure in Developing Countries, Journal of Finance, 56, 87- 130.

Bokpin, G.A. (2009). Macroeconomic Development And Capital Structure Decisions Of Firms: Evidence From Emerging Market Economies, Studies in Economics and Finance, 26, (2), 129-142.

Burucu, H. ve Öndeş, T. (2016). Türk İmalat Sanayi Firmalarının Sermaye Yapısını Etkileyen Faktörlerin Analizi, Çankırı Karatekin Üniversitesi IÏBF Dergisi, 1-25, http://dx.doi.org/10.18074/cnuiibf.303.

Buvanendra, S., Sridharan, P. and Thiyagarajan, S. (2016). Role Of Country-Specific Factors On Capital Structure Decision: Evidence From Sri Lankan Listed Firms, Global Business Review, 17 (3), 582-593.

Cansız, S. ve Sayılgan, G. (2017). Sermaye Yapısı Teorilerinin Reel Sektör Firmaları Özelinde Test Edilmesi, Verimlilik Dergisi, (2), 135 -161. 
Channar, Z.A., Maheshwari, M.B. and Abbasi, P. (2015). Determinants Of Capital Structure Of Service And Manufacturing Sectors Of Pakistani Companies Listed in Karachi Stock Exchange, Business Review, 10, (1), 72-85.

Chen, L. (2007).Determinats Of Capital Structure: An Empirical Study From UK Firms, a Dissertation Presented in Part Consideration for the Degree of MA Finance and Investment.

Cheng, H. (2014). Determinants Of Capital Structure in Asian Firms: New Evidence On The Role Of Firm Level Factors, Industry Characteristics And Institutions, University of Leicester School of Management, Thesis Submitted for the Degree of Doctor of Philosophy, UK.

Daskalakis, N., Balios, D. and Dalla, V. (2017). The Behaviour Of SMEs' Capital Structure Determinants in Different Macroeconomic States, Journal of Corporate Finance, 46, 248-260.

Deesomsak, R., Paudyal, K. and Pescetto, G. (2004). The Determinants Of Capital Structure: Evidence From The Asia Pacific Region, Journal of Multinational Financial Management14, 387-405.

De Jong, A., Kabir, R. and Nguyen, T.T. (2008). Capital Structure Around The World: The Roles Of Firm- And Country-Specific Determinants, Journal of Banking Finance, 32, 1954-1969.

Demirguc-Kunt, A. and Maksimovic, V. (1995). Stock Market Development And Firms' Financing Choices, The World Bank Policy Research Department, Policy Research WorkingPaper, 1461, 1-46.

Demirguc-Kunt, A. and Maksimovic, V. (1996). Stock Market Development And Firms' Financing Choices, World Bank Economic Review, 10, 341-369.

Demirhan, D. (2009). Sermaye Yapısını Etkileyen Firmaya Özgü Faktörlerin Analizi: İMKB Hizmet Firmaları̈̈zerine Bir Uygulama, Ege Akademik Bakış / Ege Academic Review, 9 (2), 677-697.

Dinçergök, B. (2010). Sermaye Yapısını Etkileyen Faktörlerin Mukayeseli İncelenmesi. (Yayımlanmamış Doktora Tezi). Gazi Üniversitesi Sosyal Bilimler Enstitüsü, İşletme ABD, Muhasebe ve Finansman Bilim Dalı, Ankara.

Dincergok, B. and Yalciner, K. (2011). Capital Structure Decisions Of Manufacturing Firms' in Developing Countries, Middle Eastern Finance and Economics, 12,86-100.

Drobetz, W., Pensa, P. and Wanzenried, G. (2007). FirmCharacteristics, Economic Conditions And Capital Structure Adjustments,WWZ WorkingPaper 16/07, CH-4003 Basel, forum-wwz@unibas.ch, www.wwz.unibas.ch

Elitaş, B.L. ve Doğan, M. (2013). Sermaye Yapısını Belirleyen Faktörler: İMKB Sigorta Şirketleri Üzerine Bir Araştırma, Muhasebe Bilim Dünyası Dergisi, 15, (2), 41-57.

Ekizler, H. (2016).Türk İmalat Sanayi Şirketlerinin Performanslarının Çeşitli Çok Değişkenli Yöntemlerle İncelenmesi, (Yayımlanmamış Doktora Tezi). İstanbul Üniversitesi Sosyal Bilimler Enstitüsü, İşletme ABD, Sayısal Yöntemler Bilim Dalı, İstanbul.

Frank, M. Z. and Goyal, V. K. (2009). Capital Structure Decisions: Which Factors Are Reliably Important?" Financial Management,38, (1), 1-37.

Gajurel, D.P. (2006).Macroeconomic Influences On Corporate Capital Structure, https://papers.ssrn.com/sol3/papers.cfm?abstract id=899049, 1-9, (Erişim tarihi: 4 Nisan 2018).

Hair, F. Et al. (1998). Multivariate Data Analysis, PrenticeHall, Fifth Edition, New Jersey.

Hair, F. Et al. (2010). Multivariate Data Analysis a Global Perspective, PearsonPrentice Hall, Seventh Edition, UK. Harris, M. and Raviv, A. (1991). TheTheory Of CapitalStructure, Journal of Finance, 46, 297-355.

Huang, S.G.H. and Song, F. M. (2006). The Determinants Of Capital Structure: Evidence From China, China Economic Review, 17, 14-35.

Jang, S., S., Tang, C., H. and Chen, M., H. (2008). Financing Behaviors Of Hotel Companies, International Journal of Hospitality Management, 27, 478-487.

Kalaycı, Ş. (2010). SPSS Uygulamalı Çok Değişkenli İstatistik Teknikleri, Ankara, Asil Yayın Dağıtım.

Köksal, B., Orman, C. and Oduncu, A. (2013). Determinants Of Capital Structure: Evidence From A Major Emerging Market Economy,http://mpra.ub.uni muenchen.de/48415/ (Erişim tarihi: 2 Mart 2018) 
N. Yücedağ Erdinç - G. Sayılgan 12/1 (2020) 826-847

Ling, Z.-x. and Lin, Y.-w. (2013), Macroeconomic Condition, Firm's Financial Characteristics And Capital Structure Dynamic Adjustment, The 19 1 International Conference on Industrial Engineering and Engineering Management,113-120.

Martin, P.S. and Saona, P. (2017). Capital Structure İn The Chilean Corporate Sector: Revisiting The Stylized Facts, Research in International Business and Finance, 40, 163-174.

Matias, F. and Serrasqueiro, Z. (2017). Are There Reliable Determinant Factors Of Capital Structure Decisions? Empirical Study Of SMEs in Different Regions Of Portugal, Research in International Business and Finance, 40, 19-33.

Mazur, K. (2007). The Determinants Of Capital Structure Choice: Evidence From Polish Companies, International Advances in Economic Research,13, 495-514.

Merika, A.,Theodoropoulou, S., Triantafyllou, A. andLaios, A. (2015). TheRelationshipBetween Business CyclesAndCapitalStructureChoice: The Case Of The International ShippingIndustry, TheJournal of EconomicAsymmetries, 12, 92-99

Modigliani, F. and Miller, M.H. (1958). The Cost Of Capital, Corporation Finance And The Theory Of Investment, TheAmerican Economic Review, 48, (3), 261-297.

Mokhova, N. and Zinecker, M. (2013). The Determinants Of Capital Structure: The Evidence From The European Union, Acta Universitatis Agriculturae Et Silviculturae Mendehanae Brunensis, LXI, 25332546,http://dx.doi.org/10.11118/actaun201361072533

Müslümov, A. (2001). Türkiye'de Ekonomik Krizin Halka Açık KOBİ'lere Etkisi, I. Orta Anadolu Kongresi, KOBI'lerin Finansman ve Pazarlama Sorunları, KOSGEB, Nevşehir.

Myers, S.C. (2001). Capitalstructure, Journal of EconomicPerspectives, 15, (2), 81-102.

Myers, S. C. and Majluf, N. S. (1984). Corporate Financing And Investment Decisions When Firms Have Information The Investors Do Not Have, NBER WorkingPaper Series, National Bureau of Economic Research, Cambridge, 1-57.

Nguyen, T. andWu, T. (2011). Capital Structure Determinants And Convergence, Bankers, Markets and Investors, $111,43-53$.

Okeke, E.N. and Okeke, J.U. (2016). Canonical Correlation A Veritable Tool For Decision Making, Journal of Mathematics (IOSR-JM),12, (6), 13-17

Okuyan, H. A. ve Taşcı, H.M. (2010). Türkiye'de Sermaye Yapısının Belirleyicileri: Türkiye'deki En Büyük 1000 Sanayi İşletmesinde Bir Uygulama, BDDK Bankacilık ve Finansal Piyasalar, 4, (1), 105-120.

Okuyan, H.A. ve Taşcı, H.M.( 2010). İMKB'de İşlem Gören Reel Sektör İşletmelerinde Sermaye Yapısının Belirleyicileri, Ekonomik Yaklaşım, 21, (76), 55-72.

Owolabi, S. A. and Inyang, U. E. (2013). International Pragmatic Review And Assessment Of Capital Structure Determinants, Kuwait Chapter of Arabian Journal of Business and Management Review, 2, (6), 82-95.

Ozkan, A. (2001). Determinants Of Capital Structure And Adjustment To Long Run Target: Evidence From UK Company Panel Data, Journal Of Business Finance and Accounting, 28, 175-198.

Proença, P., Laureano, R. M.S. and Laoreano, L.M. S. (2014). Determinants Of Capital Sctructure And The 2008 Financial Crisis: Evidence From Portuguese SMEs, Social and Behavioral Sciences, 150, 182-191.

Rajan, R. G. and Zingales, L. (1995). What Do We Know About Capital Structure? Some Evidence From International Data, Journal of Finance 50,1421-1460.

Ross, S.A.(1977). The Determination Of Financial Structure: The Incentive-Signalling Approach, The Bell Journal of Economics, 8, (1), 23-40.

Sayılgan, G., Karabacak, H. and Küçükkocaoğlu, G. (2006). The Firm-SpecificDeterminants Of Corporate Capital Structure: Evidence From Turkish Panel Data, Investment, Management and Financial Innovations, 3 (3),125-139.

Sayılgan, G. ve Uysal, B. (2011). Türkiye Cumhuriyet Merkez Bankası Sektörel Bilançoları Kullanılarak Sermaye Yapısını Belirleyen Faktörler Üzerine Bir Analiz: 1996 - 2008, Ankara Üniversitesi SBF Dergisi, $66,4,101-124$. 
N. Yücedağ Erdinç - G. Sayılgan 12/1 (2020) 826-847

Sheikh, A. N. andWang, Z. (2011). Determinants Of Capital Structure: An Empirical Study Of Firms in Manufacturing Industry Of Pakistan, Managerial Finance, 37, (2), 117-133.

Serghiescu, L. And Vaidean, V. L. (2014). Determinant Factors Of The Capital Structure Of A Firm- An Empirical Anaylsis, Procedia Economics and Finance 15, 1447-1457.

Taşseven, Ö. ve Çınar, S. (2015). Türkiye'de Borç Dolarizasyonunun Belirleyicileri Ve Makroekonomik Göstergeler Üzerindeki Etkileri,Social Sciences Research Journal, 4, (2), 121-141.

Temimi, A., Zeitun, R. and Mimouni, K. (2016). How Does The Tax Status Of A Country Impact Capital Structure? Evidence From The GCC Region, Journal of Multinational Financial Management, 37-38, 7189.

Terim, B. ve Kayalı, C.A. (2009). Sermaye Yapısını Belirleyici Etmenler: Türkiye'de İmalat Sanayi Örneği, Celal Bayar Üniversitesi SBE, Sosyal Bilimler7, (1), 125-154.

Titman, S. and Wessels, R. (1988). The Determinants Of Capital Structure Choice,J. Finance 43, 1-19. http://dx.doi.org/10.1111/j.1540-6261.1988. tb02585.x.

Vo, X. V., (2017). Determinants Of Capital Structure in Emerging Markets: Evidence From Vietnam, Research in International Business and Finance,40, 105-113.

Zein, A., (2016). Can Macroeconomic Factors Explain The Choice Of Capital Structure? A Study of Listed NonFinancial Firms in Sweden, Department of Business Studies, Master Thesis, Uppsala University, Sweden.

https://www.kap.org.tr/tr/bist-sirketler(Erişim tarihi: 28 Mayıs 2017)

http://www.borsaistanbul.com/sirketler/islem-goren-sirketler(Erişim tarihi: 10 Ocak 2017)

www.tcmb.gov.tr(Erişim tarihi: 10 Ocak 2017)

https://www.kosgeb.gov.tr/Content/Upload/Dosya/Mali\%20Tablolar/KSEP/Kobi Stratejisi ve Eylem Plani (2015-2018).pdf (Erişim tarihi: 13 Ağustos 2018) 